NBER WORKING PAPER SERIES

ON

HISTORICAL FACTORS IN LONG RUN GROWTH

LONG-TERM TRENDS IN HEALTH, WELFARE, AND ECONOMIC GROWTH

IN THE UNITED STATES

Dora L. Costa

Richard H. Steckel

Historical Paper 76

NATIONAL BUREAU OF ECONOMIC RESEARCH

1050 Massachusetts Avenue

Cambridge, MA 02138

November 1995

Prepared for a forthcoming NBER conference volume Health and Welfare During

Industrialization, Roderick Floud and Richard $\mathrm{H}$. Steckel, editors. We have benefited from the comments of the conference participants and of two anonymous referees. Dora Costa gratefully acknowledges the support of a NIA Aging Fellowship at the National Bureau of Economic Research and of NIH grants AG12651-01A1 and AG10120-05. Richard Steckel gratefully acknowledges the support of a fellowship at Harvard University's Charles Warren Center and of Ohio State University. This paper is part of NBER's research program in the Historical Development of the American Economy. Any opinions expressed are those of the authors and not those of the National Bureau of Economic Research.

(c) 1995 by Dora L. Costa and Richard H. Steckel. All rights reserved. Short sections of text, not to exceed two paragraphs, may be quoted without explicit permission provided that full credit, including $\odot$ notice, is given to the source. 


\title{
LONG-TERM TRENDS IN HEALTH, WELFARE, AND ECONOMIC GROWTH IN THE UNITED STATES
}

\begin{abstract}
We present evidence showing that the course of economic growth and of health, as measured by stature, Body Mass Index (BMI), mortality rates, or the prevalence of chronic conditions, diverged in the nineteenth century and converged in the twentieth. To analyze the change in welfare resulting from changes in health, we estimate a Human Development Index and a Borda Ranking and we calculate Usher-adjusted incomes and the willingness to pay for a reduction in mortality risk. Prior to the Civil War the increase in income was insufficient to compensate for the decline in health, whereas improvements in health outpaced economic growth in the twentieth century. We identify numerous possible causes of the nineteenth century decline in health, including greater exposure to disease, hardship created by the Civil War, and rising inequality.

Our evidence on trends in waist-hip ratio, BMI, and the prevalence of chronic conditions at older ages suggests that early life conditions may exert an impact on mortality and morbidity that is not manifest until older ages. The dramatic twentieth century improvement in early life conditions implies that cohorts who are now approaching their sixties will experience a much greater rate of increase in health and longevity than past generations.
\end{abstract}

Dora L. Costa

Department of Economics

MIT

50 Memorial Drive

Cambridge, MA 02139

and NBER

\author{
Richard H. Steckel \\ Department of Economics \\ 410 Arps Hall \\ Ohio State University \\ 1945 North High Street \\ Columbus, OH 43210-1172 \\ and NBER
}




\section{Introduction}

Economists and historians have long been intrigued by the connection between health and economic growth. Because health is an input to economic growth, long run increases in living standards may be sped by the improving health of a population. People in better health are able to increase their productivity and output. At the same time, economic growth enables people to purchase the nutrition, sanitation, shelter, and medical care that are so necessary to health.

However, economic growth is not always benign. Industrialization was generally associated with increased urbanization, crowded factories and tenements, and the pacing of workers by machines. Economic growth might therefore lead to a deterioration in health. Examining the interrelationship between industrialization and health will help us understand how adverse effects associated with economic growth can be mitigated.

Establishing the secular trend in health and understanding its causes is also important for understanding the present. The past is still with us both because older generations are still with us and because physiological processes have an intergenerational reach. The oldest generation alive today was born when lile expectancy at birth was only 50. A growing body of evidence indicates that chronic diseases at older ages and premature older age mortality are, to a considerable degree, the result of exposure to infectious diseases, malnutrition, and other types of biomedical and socioeconomic stress early in life (see the papers collected in Barker 1992). The health of this generation matters for understanding the health of succeeding generations. Recent studies suggest that a mother's ability to nourish her baby is established during her own life, including the fetal stage (see Barker 1994).

Past trends in health are also important for predicting morbidity and mortality. Recent forecasts have, for the most part, been based on information derived from surveys that began to be collected only in the late 1960s. These may not provide a long enough period of observation 
to differentiate adequately between short-term fluctuations and the underlying long-term trends over the entire twentieth century. They are also based upon empirical extrapolations and do not directly reflect physiological processes.

This paper reviews the evidence on economic growth and health as measured by stature and mortality rates in the nineteenth and twentieth centuries. We also present new evidence on BMI, lean body mass, waist-hip ratio, and the prevalence of chronic conditions. These anthropometric variables are useful predictors of both overall and disease specific mortality and morbidity at later ages and provide us with a more complete picture of past health than stature and mortality ratcs alone. The twentieth century has witnessed a dramatic improvement in both health and economic indicators. The improving trend in health indicators remained unbroken even by the Great Depression. In the nineteenth century the opposite situation prevailed - health status began to decline in about 1830 while income continued to rise. Examining the interaction between environmental variables and anthropometric variabics in both the nineteenth and the twentieth centuries will enable us to understand the factors underlying the twentieth century improvement in health and improve our predictions of future trends. It will also tell us whether a decline in health was a necessary cost of industrialization. We also consider implications of changes in health for human welfare. One of the central question of this paper is whether the bundle of evidence on health and economic performance leaves us with little more than intuitive notions of the net change in human welfare or whether it is possible to quantify the dimensions of welfare change.

\section{Trends in Economic Indicators}

Numerous indicators establish that the nineteenth and twentieth centuries were a period of longterm improvement in living standards as conventionally measured. Although scholars have 
speculated about the course of economic development in the late eighteenth and early nineteenth centuries, the first reasonably comprehensive evidence on performance was not collected until the federal census of 1840. Gallman's estimates of output from this and later censuses combined with prices and imputations for omitted categories, such as services, indicate that real net national product grew at nearly four percent per annum from 1840 to 1900 , a phenomenon fueled by a transportation revolution, technological change, improved capital markets, capital accumulation, and other factors (see tables from Davis et al. 1972). Although the rate of growth slowed to slightly more than three percent in the period from 1900 to 1960 , the growth of factor inputs also fell. Output per worker grew at approximately 1.4 percent per year from 1840 to 1960 , a performance similar to that achieved by other early industrializers.

Despite macroeconomic fluctuations that caused significant variation in real wage growth, real wages increased during the nineteenth and twentieth centuries. In the first half of the nineteenth century, the real wages of men hired by army quartermasters increased substantially across all regions of the country and within a moderately broad base of occupations. Hefty gains occurred in the 1820 s and early 1830 s but the trend was broken by the economic distress of the late $1830 \mathrm{~s}$. Although the experience of artisans and unskilled laborer differed somewhat across regions, the overall gains were in the range of 30 to 60 percent from the early 1820s to the mid 1850s (Goldin and Margo 1992). Wages continued to rise in the second half of the nineteenth century, increasing by one third between 1860 and 1900 (Margo 1993). In the twentieth century, real annual wages increased by 1.43 per annum on average from 1900 to 1929 , by 2.35 percent from 1948 to 1973 , and by 0.46 percent after 1973 . Benefits as a fraction of compensation continued to rise (Goldin 1994).

Changes in the composition of the labor force signaled the rise of an industrial economy. At the beginning of the century, farming dominated economic activity. According to Weiss (1991) agriculture absorbed 72 percent of the labor force in 1810 but by 1840 had slipped to 67 percent 
and by 1860 to 56 percent. A majority of those employed worked outside agriculture by 1890 , but farm-sector employment continued to grow in absolute numbers, reaching a peak in 1910. The transformation to an industrial service economy was completed in this century and by 1950 only 12 percent of the labor force was in agriculture.

The economic transformation of the nineteenth century registered gradually in the shift of population from rural to urban areas (see Series A, U.S. Bureau of the Census 1975: 52-72). Reflecting the country's agricultural orientation, less than 8 percent of the population lived in urban areas (places of 2,500 or more population). However, the transition to urban living was less rapid than changes in the labor force, indicating that an important share of early industrial activity took place in rural or semi-rural areas. Between 1810 and 1840 the labor force involved in agriculture declined by approximately 22 percentage points, but the population living in urban areas grew from 8 to only 11 percent. As late as 1860 less than 20 percent of the population lived in cities or towns of more than 2,500 residents and only 10 percent lived in cities with a population of 50,000 or more. The surge in city growth awaited large scale immigration from Europe following the Civil War and by 1900 nearly 40 percent of the population lived in urban areas.

\section{Trends in Health}

\subsection{Heights}

The most abundant evidence on long-term trends in health was recorded by military organizations. From the mid-1700s heights were often recorded as part of the mustering process to help identify deserters, to assess fighting strength, and to insure that soldiers received their proper pay. Figure 1 presents trends in the heights of native-born soldiers from the eighteenth through the twentieth 
Figure 1: Mean Heights of White, Native-Born Males by Birth Cohort, 1710-1970

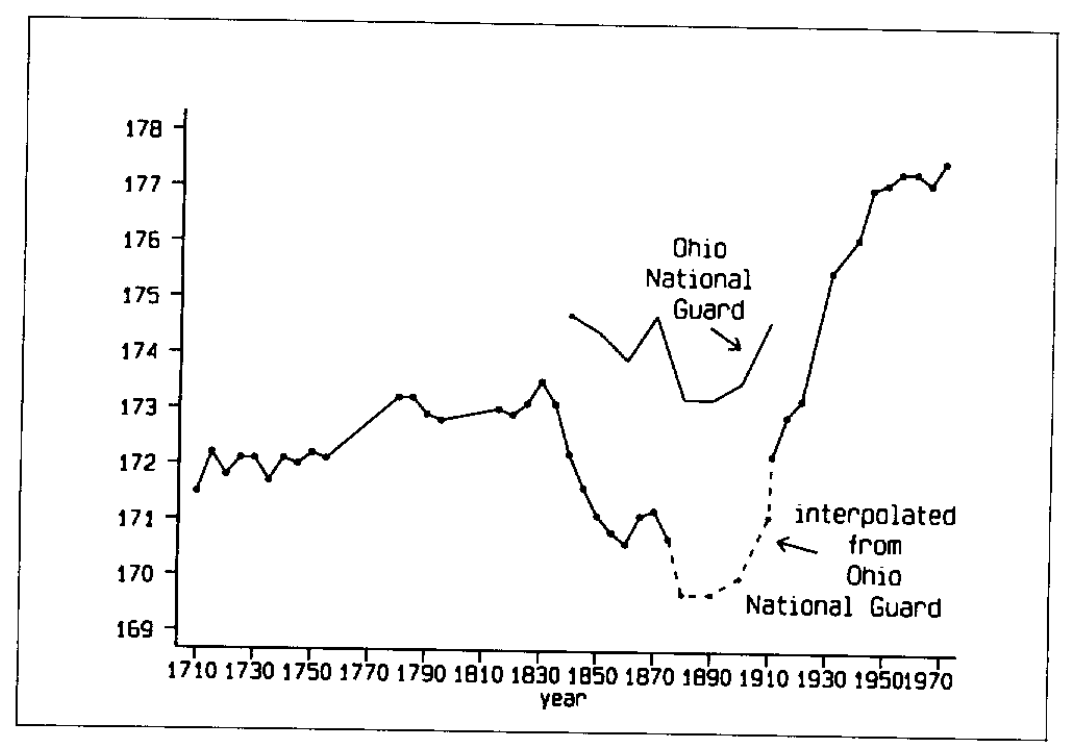

Note. Compiled from Steckel (1992), Ohio National Guard Recruits, 1959-1962 NHES, 1971 NHANES, and 1991 NHIS. The data used in Steckel (1992) come from Fogel (1986). Steckel and Haurin (1982), and from several of the data sets listed in the Appendix (Union Army Recruits in White Regiments in the United States, 1861-1865. French and Indian War Army Recruits, American Revolution Army Recruits, United States Army Recruits, 1815-1820, and United States Army Recruits, 1850-1855). Year of birth is centered at the marks. The interpolation is from the Ohio National Guard. Estimates for 1955-1970 were adjusted to account for biases resulting from self-reporting in the 1991 and 1981 NHIS.

centuries and of native-born men in the last decades of this century. ${ }^{1}$ The data, which are arranged by birth cohort, show that troops who fought in the French and Indian War of the 1750s and the 1760s or who fought in the American Revolution of the 1770s nearly attained 1930s heights of $175 \mathrm{~cm}$. Cohorts born from the early 1700 s to those born in 1830 achieved a gradual increase in average stature of approximately one centimeter. Average heights fell by approximately $4 \mathrm{~cm}$ in the ensuing half century, reaching a trough among births in the $1880 \mathrm{~s}^{2}$ Thereafter, American

\footnotetext{
${ }^{1}$ Since the sample sizes are substantial, particularly for those periods before the large wars, the major movements in the series are unlikely to represent sampling variation. In fact, the difference in average height between rejectees and those who served in the Union Army was 0.25 inches. The averages have been corrected for minimum height standards.

${ }^{2}$ No national height series is available for the end of the nineteenth century. Interpolation was based upon the assumption that the time pattern for the country followed that for Ohio.
} 
men experienced the familiar secular increase in stature of recent times, gaining approximately six centimeters by the mid-twentieth century. The secular increase in heights continues in recent decades, although at a much slower pace.

The nineteenth-century decline in heights was initially viewed with caution or skepticism since it clashed with well-established views on the economic prosperity of the era. Steckel and Haurin discovered the mid-nineteenth century downturn among the Ohio National guard in 1981, but delayed publication until confirmation of a downturn in health was available and some reasonable explanations could be provided. Corroborating evidence was obtained from various sources including stature, weights, and mortality rates. West Point cadets lost approximately $1.4 \mathrm{~cm}$ in height between cohorts of the $1820 \mathrm{~s}$ to those of the $1860 \mathrm{~s}$, which was followed by recovery in the $1870 \mathrm{~s}$, a pattern of change that existed across regions and occupational groups (Komlos 1987). Their loss in height was less than that experienced by regular troops, possibly because the cadets came from a higher socioeconomic stratum.

Life expectancy at age 10 follows a pattern similar to that of heights. After rising for most of the eighteenth century, life expectancy begins to decline during the 1790 s and continues to do so for the first half of the nineteenth century (Fogel 1986). Mortality rates for native-born adults calculated from geneaologies also identify a loss in health during the first half of the nineteenth century. Life expectation for men at age 20 declined from approximately 47 years at the beginning of the century to slightly less than 41 years in the 1850 s. Among women the decline was steeper: from nearly 48 years in $1800-1809$ to 37.1 years in the 1840 s. Recovery to levels of the early 1800s was not attained until the end of the century (Pope 1992).

Evidence for the South suggests that the cycle in heights may have been a national phenomenon. Among slaves, the heights of children born after approximately 1830 declined by two and half to seven and half centimeters in the two decades following (Steckel 1979a). The heights of slave women measured as adults declined by more than one centimeter over two decades 
for those born after 1810. In contrast, the heights of adult men rose by more than one centimeter over the same time period. Consistent with the trend for women and children, the infant mortality rate calculated from plantation records approximately doubled during the early 1800 s, reached a peak in the 1830s and then declined to its former level in the late 1850s (Steckel 1979b). Data on the heights of southern white men who signed amnesty oaths in the 1860s suggests that the loss in stature extended beyond slaves. The average stature of these men born before 1820 was approximately one centimeter above those born in the 1820s (Margo and Steckel 1992).

The implications of changes in height for mortality have been studied only recently. ${ }^{3}$ Costa (1993b) finds that the functional relation between height and subsequent mortality is similiar among a sample of 322 Union Army recruits measured at ages 23-49 who lived to age 55 and are observed over a twenty year period and among modern, Norwegian males aged 40-59 observed over a seven year period. Both the Norwegian curve and the U.S. curve show that mortality first declines with height to reach a minimum height close to $187 \mathrm{~cm}$ and then starts to rise. A similar relationship is found between height and self-reported health status (Fogel et al. 1994). Height appears to be inversely related to heart and respiratory diseases and positively related to the hormonal cancers (Barker 1992). The relationship between height and mortality remains unchanged controlling for socio-economic covariates, such as occupation, nativity, and urbanization. The Norwegian height curve suggests that had the distribution of heights in the Union Army sample been the same as in the 1991 National Health Interview Survey, older age mortality rates would have fallen by $9 \%$.

Data from developing countries suggests that the impact of height on productivity is substantial. Using data for rural south India, Deolaliker (1988) finds that the elasticity of wage rates with respect to heights is in the range of 0.28 to 0.66. Haddad and Bouis (1991) report

\footnotetext{
${ }^{3}$ The relationship between height and mortality for slaves was studied earlier, e.g. Friedman (1982).
} 
that wages in the rural Philippines are strongly ini.uenced by height. In an extension, Foster and Rosenzweig (1992) find that height and calories have particularly large effects on piece rate wages. Data from the antebellum American South shows that height and weight were positively associated with value, suggesting that better fed, healthier slaves were more productive (Margo and Steckel 1982).

\subsection{BMI}

The body mass index (BMI), defined as weight in kilograms divided by the square of height in meters, may be an even stronger determinant of productivity, morbidity, and mortality than height. The relation between weight and mortality among Union Army veterans measured at ages 50-64 and observed from age 50 until 75 resembles that seen among modern, Norwegian males (Costa 1993b). Mortality risk first declines rapidly at low weights as BMI increases, stays relatively flat over BMI levels from the low to high twenties, then starts to rise again, but less steeply than at very low BMIs. Among modern, American males aged 50-64 the relationship between BMI and self-reported health status, the number of bed days, the number of doctors' visits, and the number of hospitalizations follows a similar U-shaped pattern (Costa 1996). Costa (1993b) argues that the low weights of Union Army veterans can partially explain why mortality for their cohort was higher than for cohorts today. Had it been possible to shift the BMI distribution of Union Army veterans one standard deviation to the right so that the mean would be equivalent to that prevailing in modern Norway, the implied $14 \%$ reduction in the mortality rate would explain roughly $20 \%$ of the total decline in mortality above age 50 from 1900 to 1986, a percentage greater than that explained by changes in height. ${ }^{4}$

\footnotetext{
${ }^{4}$ When height and weight are jointly related to subsequent mortality, the predicted decline explains $15 \%$ of the total decline in mortality. When height and weight are jointly related to subsequent morbidity, the predicted decline explains $35 \%$ of the total decline in morbidity (Fogel et al. 1994).
} 
A U-shape similar to that observed between mortality and BMI is also observed between labor force non-participation and BMI. Costa (1996) finds that among Union Army veterans measured at ages 50-64, the relative risk of labor force non-participation increases sharply at both high and low levels of BMI, but that height and labor force non-participation are not related. She finds a similar U-shaped relation between BMI and labor force non-participation in a sample of white men aged 50-64 in 1985-1991. However, the relative risk at high BMI levels is much lower. In both samples, the BMI that maximized labor force participation was around 25 - statistically indistinguishable from the BMI that minimizes relative mortality risk. Had the distribution of BMI in the Union Army sample been the same as that observed today, the probability of nonparticipation would have fallen by $10 \%$. Assuming that the probability of non-participation among all men would have fallen by $10 \%$, the total output of male workers would have increased by $1.7 \%$ (Costa 1996).

Evidence from developing countries also demonstrates the importance of BMI. Deolaliker (1988) finds that the elasticity of farm output with respect to BMI is as large as 2 . As previously noted, the elasticity of wage rates with respect to heights was only in the range of 0.28 to 0.66 . Behrman and Deolaliker (1989) find that market productivity in India is heavily influenced by BMI during the off peak season, but is not influenced by height in either the peak or off peak season. ${ }^{5}$

Evidence on BMI trends is sparse. BMI of Citadel cadets aged 18 declined from 20.2 in the 1870 s to 19.4 in the 1890 s and rose to 21.4 by 1920 . BMI of cadets aged 20 rose from 20 in the 1890 s to 23.0 in the 1920 s (Coclanis and Komlos 1995). This time pattern agrees with that of stature. Cuff (1994) finds a similarly low BMI of 19.8 at age 18 and of 20.8 at age 21 among West Point cadets from 1874 to 1994 . Evidence from military sources, however, indicates that average

\footnotetext{
${ }^{5}$ These relations are derived from instrumental variables estimates and thus account for potential endogeneity between BMI and wage rates.
} 
BMI for a more representative sample of the population may have been higher. One of us has collected a sample of the detailed anthropometric measurements on Union Army soldiers carried out by the United States Sanitary Commission from 1863 to 1865 (see Costa 1994). These show that average BMI among recruits age 18-19 was 21.7 and that among recruits age 20-21 was 22.5. Among native white army recruits aged 20-24 in 1892-1897, average BMI was 22.0 (Hathaway and Foard 1960).

Figure 2 uses military sources, data on Union Army veterans collecting pensions, and recent surveys to estimate mean BMI by year of measurement and by age group. ${ }^{6}$ BMI among men aged 20-24, 25-29, and 30-34 declined between 1864 and 1894, consistent with the decline in heights. But, at ages 35-39 and 40-49 the pattern is reversed. One possible explanation may be the time of measurement. Men in 1892-1897 were measured at induction into the army. Men in 1863-1865 were measured while in the army and their experience while in the army may have affected the relationship between BMI and age. However, when men who stated that they were either more or less vigorous than before joining the army are deleted from the sample, mean BMI

\footnotetext{
${ }^{6}$ The age groups are ages $18-19,20-24,25-29,30-34,35-39,40-49$, and 50-64. The years are 186.3-1864, 1892-1897, 1900, 1943-1944, 1959-1962, and 1991. Anthropometric measurements carried out by the Sanitary Commission on Union Army soldiers aged 18-49 were used for 1863-1865, native white army recruits aged 20-39 were used for 1892-1897, and Union Army veterans aged 50-64 for 1900, as well as the 1959-1962 NHES and the 1991 NHIS.

The results for 1892-1897 are roughly consistent with medico-actuarial data for 1885-1908 in which mean BMI at ages $20-24,25-29,30-34$, and $35-39$ is $22.2,22.8,23.5$, and 23.9 , respectively, after adjusting for indoor clothing by substracting one inch from height to account for heels and five pounds from weight to account for clothes (Table 3 in Hathaway and Foard 1960). Medico-actuarial data for older ages yields a greater BMI. Among men aged 40-49 mean BMI is approximately 24.4 and among men 50-64 24.7. Studies of New York in the 1920s and Illinois in 1927-1929 in which men were measured without clothes also indicate that mean BMI at ages 40-49 was about 24.3 and 24.9 at ages 50-59. However, a study of New York in 1934 yields a mean of 23.1 for men aged 40-49 and 50-59 (Table 6 in Hathaway and Foard 1960). It is not surprising that BMI is higher among men in the medico-actuarial data than among Union Army veterans. The medico-actuarial data contains a high proportion of professional men and among Union Army veterans age 50-64 collecting pensions men who were either current or retired professionals of proprietors had a mean BMI of 24.3 while men who were either current or retired laborers had one of 22.5 . Differences in BMI by occupational class at young ages among Union Army recruits in 1863-1865 were not as pronounced as differences at older ages among veterans.
} 
Figure 2: Mean BMI by Age Group and Year, 1863-1991

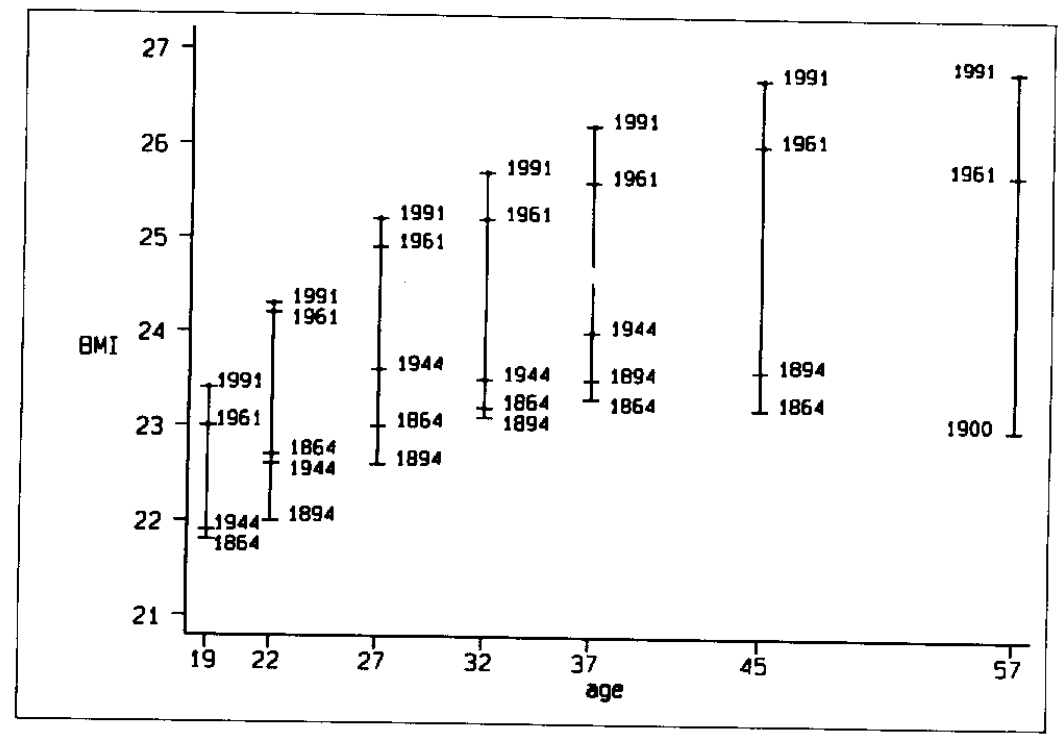

Note: The age groups are centered at the marks and are ages 18-19, 20-24, 25-29, 30-34, 35-39, 40-49, and 50-64. For some years BMI is not available for a specific age group. Calculated from Anthropometric Statistics of Union Army Recruits, Early Indicators of Later Work Levels, Disease, and Death, Hathaway and Foard (1960), Karpinos (1958), 1959-1962 NHES, and 1991 NHIS. See the Appendix for a description of these data sets.

remains unchanged. Although there are differences in BMI between 1863-1865 and 1892-1897, these are marginal compared to those observed between the nineteenth century and the post World War II era. The differences in BMI between the nineteenth and the late twentieth century are especially pronounced at older ages.

Why the difference in BMI between the nineteenth and twentieth centuries should be especially pronounced at older ages and why differences in BMI by occupational class were small at young ages and large at old ages can be explained by a wide array of factors. These include the accumulated effects of work intensity and of working conditions, early life conditions that led to chronic conditions that only became evident at older ages, and the accumulated effects of differences in nutritional intakes and physical activity. Socioeconomic factors have been found to affect the rate of deterioration in health with age. A recent study of musculoskeletal capacity over a three and a half year period finds that not only was musculoskeletal capacity lower among 
men in physical rather than mental or mixed work, the rate of deterioration in musculoskeletal capacity among men in physical work was greater, perhaps because of the increasing prevalence of musculoskeletal diseases (Nygård et al. 1988).

It is not enough to consider BMI alone in comparing health across a century. BMI consists of both fat and lean body mass. Lean body mass in turn consists of skeletal, muscle, and visceral mass. A lower lean body mass index among Union Army soldiers compared to men today would be an indicator that Union Army soldiers were at greater mortality and morbidity risk. A reduction in skeletal, but not in visceral mass, can arise from mild to moderate undernourishment (Soares and Shetty 1991). Severe undernourishment affects visceral mass as well (Shetty 1984). Table 1 shows that for all age groups the estimated percentage of body fat was lower among Union Army soldiers compared to men in the NHES. However, estimated lean Body Mass Index (calculated from total weight minus fat mass in kilograms) among Union Army soldiers was also lower. $^{7}$

\subsection{Central Body Fat}

Although height and weight are the most readily available anthropometric measures, studies of recent populations suggest that measures of central or abdominal body fat are better markers than BMI of risk of death, especially risk of fatal heart disease (e.g. Folsom et al. 1993). Abdominal fat distribution is associated with antecendents of cardiovascular disease such as hypertension,

\footnotetext{
${ }^{7}$ Because the data on Union Army soldiers collected by the United States Sanitary Commission contains not only information on height and weight, but also information on a wide array of anthropometric measures, including waist and hip girth and shoulder breadth, these can be used to estimate the percentage of body fat of Union Army veterans. Using the National Health Examination Survey (NHES) of 1959-1962, the percentage of body fat was estimated from the sum of biceps and subscapular skin folds using the method of Durnin and Womersley (1974). The percentage of body fat was then related to BMI, waist girth, and waist girth divided by shoulder breadth entered up to a cubic term by means of an ordinary least squares regressions for the age groups 18-19, 20-29, 30-39, and $40-49$. These anthropometric measures were able to explain $60-70 \%$ of the variation in body fat. The percentage of body fat among Union Army soldiers was then predicted from these regression equations.
} 
Table 1: BMI, Percentage of Body Fat and Lean BMI Among Union Army Soldiers and White American Men in 1959-1962 in the National Health Examination Survey (NHES)

\begin{tabular}{|c|c|c|c|c|c|c|c|c|}
\hline & \multicolumn{4}{|c|}{ Union Army } & \multicolumn{4}{|c|}{ NHES } \\
\hline & & $\begin{array}{c}\% \\
\text { body }\end{array}$ & lean & & & $\begin{array}{c}\% \\
\text { body }\end{array}$ & lean & \\
\hline age & BMI & fat & BMI & obs & BMI & fat & BMI & obs \\
\hline $18-19$ & 21.7 & 18.4 & 17.6 & 689 & 22.9 & 19.5 & 18.3 & 121 \\
\hline $20-29$ & 22.8 & 18.4 & 18.6 & 2869 & 24.5 & 20.8 & 19.1 & 568 \\
\hline $30-39$ & 23.3 & 21.9 & 18.1 & 680 & 25.5 & 22.9 & 19.5 & 693 \\
\hline $40-49$ & 23.3 & 23.4 & 17.8 & 204 & 27.0 & 27.4 & 18.7 & 636 \\
\hline
\end{tabular}

Note. The numbers for Union Army soldiers were estimated after deleting men who whose vigor had been either reduced or improved by the war. Including these men does not change the results.

non-insulin dependent diabetes, high plasma concentrations of atherogenic lipids, and low concentrations of high density lipoprotein cholesterol (OhIson et al. 1985; Hartz, Rupley, and Rimm 1984; Vague 1956; Blair et al. 1984; Folsom et al. 1989; Soler et al. 1988; Noord et al. 1990). A 23-year follow-up study of World War II soldiers whose waist-hip ratio was measured at ages 16-35 found that the relative risk of ischaemic heart disease mortality of a 0.10 increase in the waist-hip ratio was 1.13 (Terry et al. 1992).

Table 2 compares waist-hip ratio and BMI among Union Army soldiers and among World War II soldiers. The comparison is striking. While BMI is greater among World War II recruits, waist-hip ratio is greater among Union recruits. These results suggest that the prevalence of heart disease at older ages among Union Army recruits should have been higher than among World War II veterans, a prediction consistent with the findings of Fogel et al. (1994), who report that cardiovascular disease was 2.9 times as common among Civil War veterans compared to World War II veterans. In fact, if World War II soldiers had had the waist-hip ratio of Union Army soldiers, their risk of death from ischaemic heart disease 23 years after follow-up would have been 1.04 times greater for men measured at ages 16-20, 1.09 times greater for men measured 
Table 2: Comparison Waist-Hip Ratio (WHR) and Body Mass Index (BMI) with U.S. World War II Soldiers

\begin{tabular}{|c|rcc|rcc|}
\hline & \multicolumn{3}{|c|}{ Civil War } & \multicolumn{3}{c|}{ World War II } \\
\hline age & \multicolumn{1}{|c|}{ obs } & WHR & BMI & \multicolumn{1}{c|}{ obs } & WHR & BMI \\
\hline $16-20$ & 992 & 0.843 & 21.8 & 33305 & $0.820^{\ddagger}$ & $22.7^{\ddagger}$ \\
$21-25$ & 1540 & 0.854 & 22.9 & 20869 & $0.833^{\ddagger}$ & $23.2^{\ddagger}$ \\
$26-30$ & 709 & 0.864 & 23.2 & 21121 & $0.850^{\ddagger}$ & $23.8^{\ddagger}$ \\
$31-35$ & 347 & 0.867 & 23.3 & 8053 & 0.862 & $24.0^{\dagger}$ \\
\hline
\end{tabular}

Note: The symbol $\$$ indicates significance at the $1 \%$ level and $\dagger$ at the $5 \%$ level. Data on Civil War soldiers are from Anthropometric Statistics of Union Army Recruits described in the Appendix. Data on World War II soldiers are from Terry et al. (1992).

at ages 21-25, and 1.07 times greater for men measured at ages 26-30. Their risk of death from cerebrovascular disease would have been 1.09 times greater for men measured at ages 16-20,1.07 times greater for men measured at ages 21-25, and 1.05 times greater for men measured at ages 26-30.

Although a high waist-hip ratio, like all measures of body fat, is commonly regarded as a problem of affluent societies, evidence from a series of studies by Barker and his collegues (collected in Barker 1992) suggests that a high waist-hip ratio reflects maternal or fetal undernutrition. They find that waist-hip ratio falls with increasing birthweight and rises as the ratio of placental weight to birthweight rises. Both low birthweights and high ratios of placental weight to birthweight may be markers of maternal and fetal undernutrition. One possible explanation for the relationship between waist-hip ratio and maternal and fetal undernutrition is that sustained adrenal overactivity, initiated by early growth restraint, increases abdominal fat depositions. The available evidence on nineteenth century birthweights suggests that in mid-nineteenth century Philadelphia the poor had high birthweights by mid-twentieth century standards (Goldin and Margo 1989), but that the poor in end of the nineteenth century Boston did not (Ward 1993). Nothing is known about the ratio of placental weight to birthweight in the nineteenth century. However, the lean BMI of Union Army soldiers may be an indicator of fetal malnutrition. It is known that some 
low weight birth babies have disproportionate retardation of the abdominal viscera, especially the liver (Gruenwald 1963). ${ }^{8}$ An examination of Union Army recruits suggests that socio-economic factors do play a role in explaining differences in waist-hip ratios. Controlling for age, BMI, and other characteristics, laborers had a greater waist-hip ratio than farmers, artisans, professionals and proprietors, and farm laborers and the waist-hip ratio of the foreign-born was greater than that of the native-born. Both laborers and the foreign-born faced more severe environmental stresses compared to the native-born or men in other occupational classes.

\subsection{Chronic Conditions}

The evidence that has been presented on anthropometric measures suggests that in the past men should be at much greater risk of chronic disease than men today, especially for heart and respiratory diseases which are associated with shorter heights and higher waist-hip ratios. This is borne out by the findings of Fogel et al. (1994) who find that heart disease was 2.9 times as prevalent, musculoskeletal and respiratory diseases were 1.6 times as prevalent, and digestive diseases were 4.7 times as prevalent among Union Army veterans aged 65 or over in 1910 as among World War II veterans of the same ages in 1985-1988. In fact, because nineteenth century physicians did not have the technological capability to diagnose certain conditions, relative prevalence rates may be underestimated. These rates suggest that the prevalence rate of heart disease among the elderly has declined at a rate of 12.8 percent per decade since 1910 , while musculoskeletal and respiratory diseases each have declined at a rate of 5.9 percent per decade. Furthermore, chronic conditions began at much earlier ages among the cohorts that reached age 65 between 1900 and 1915 than among the cohorts that reached the same age in the 1980s. Within the earlier cohort, over 7 percent of those between ages 30 and 35 had circulatory diseases and

\footnotetext{
${ }^{8}$ It is not known whether this retardation persists into adult ages.
} 
Table 3: Prevalence of Chronic Conditions by Cohort and Age (Percentages) Among Union Army Veterans

\begin{tabular}{|l|l|ll|lr|}
\hline & \multicolumn{5}{|c|}{ year of birth and age } \\
\hline & $1820-29$ & \multicolumn{2}{|c|}{$1830-39$} & \multicolumn{2}{c|}{$1840-49$} \\
\hline & $65-74$ & $55-64$ & $65-74$ & $55-64$ & $65-74$ \\
\hline rheumatism & $62.4^{\dagger}$ & $54.5^{\ddagger}$ & 71.9 & 65.2 & 77.2 \\
heart & 67.3 & $54.5^{\ddagger}$ & 72.0 & 69.3 & 75.7 \\
varicose veins & 29.7 & $23.4^{\ddagger}$ & 36.7 & 34.1 & 35.1 \\
hemorroids & $33.7^{\dagger}$ & $33.4^{\ddagger}$ & $40.1^{\ddagger}$ & 41.6 & 53.6 \\
hernia & $27.7^{*}$ & 27.4 & 38.5 & 36.6 & 30.6 \\
respiratory & $26.7^{* \dagger}$ & $27.1^{\ddagger}$ & 41.2 & 36.6 & 42.6 \\
genito-urinary & 19.8 & $10.4^{\ddagger}$ & 23.6 & 18.7 & 28.3 \\
stomach & $34.7^{* \dagger}$ & $43.8^{\ddagger}$ & 56.1 & 49.7 & 46.0 \\
diarrhea & 26.7 & 26.8 & 32.1 & 28.3 & 28.3 \\
\hline
\end{tabular}

Note. The symbols $*$ and $\dagger$ indicate that prevalence rates for the 1820-1829 cohort are significantly different at at least the $10 \%$ level from those for men born in 1830-1839 and 1840-1849, respectively. The symbol $\ddagger$ indicates that prevalence rates for men born in $1830-1839$ are significantly different from those for men born in 1840-1849.

Prevalence rates for men aged 65-74 in 1830-1839 and in 1840-1849 were calculated by reweighting the age distribution to reflect that for men born in 1820-1829. Prevalence rates for men aged 55-65 in 1840-1849 were calculated by reweighting the age distribution to reflect that for men born in $1830-1839$.

another 5 percent has incapacitating musculoskeletal disirases.

Examining the data used in Fogel et al. (1994) by cohort suggests that prevalence rates for chronic conditions among cohorts who were born in 1840-1849 were higher than those for cohorts who were born in 1830-1839 and 1840-1849 (see Table 3). Among men aged 65-74, those who were born in 1820-1829 were significantly less likely to suffer from rheumatism, hemorroids, respiratory disorders, hernias, and stomach disorders compared to men born in 1840-1849. Those born in 1830-1839 were less likely to suffer from hemorroids compared to those born in 1840-1849. Among men aged 55-64, those who were born in 1830-1839 were significantly less likely to have varicose veins, rheumatism, heart disease, hemorroids, respiratory disorders, stomach disorders, and genito-urinary conditions. It is suggestive that there were no 
differences by cohort in conditions that could not possibly be related to early life environmental factors, such as injury and gunshot wounds.

Although no evidence is yet available on the impact of specific chronic conditions on labor supply in the nineteenth century, recent U.S. data suggests that chronic conditions such as heart disease, arthritis and other musculoskeletal conditions, and respiratory disorders substantially reduce hours worked and the probability of labor force participation and this reduction in labor supply accounts for up to $45 \%$ of the decline in earnings observed among middle-aged men (Bartel and Taubman 1979; Yelin and Katz 1991; Burkhauser et al. 1986). The high prevalence of chronic conditions among men aged 65 and over in 1910 suggests that the impact of disease on labor productivity may have been substantial.

\subsection{Trends in the Distribution of Health}

The evidence that we have presented indicates that by all measures of health, those born in the nineteenth century fared much worse than those born in the twentieth and those born in the latter half of the nineteenth century were worse off than those born in the first half. Yet it is not enough to examine aggregate health. Although the impact of inequalities in health on aggregate production and output has not yet been incorporated in computable general equilibrium models, the intuition of economists has long been that long-run economic growth may be slowed if the health of a large fraction of the population is so poor that this fraction of the population is too unhealthy to increase its productivity and output. High mortality rates might also affect incentives to invest in human capital.

One way to establish changes in the distribution of health is to examine health differentials by occupational class. The data on heights provides the longest series on the distribution of health by occupational class. Figure 3 illustrates height differentials by occupational class for ten year cohort intervals among white, native-born males ages 25-49. Height differentials by oc- 
Figure 3: Mean Height Differentials by Occupational Class by Birth Cohort, 1710-1970

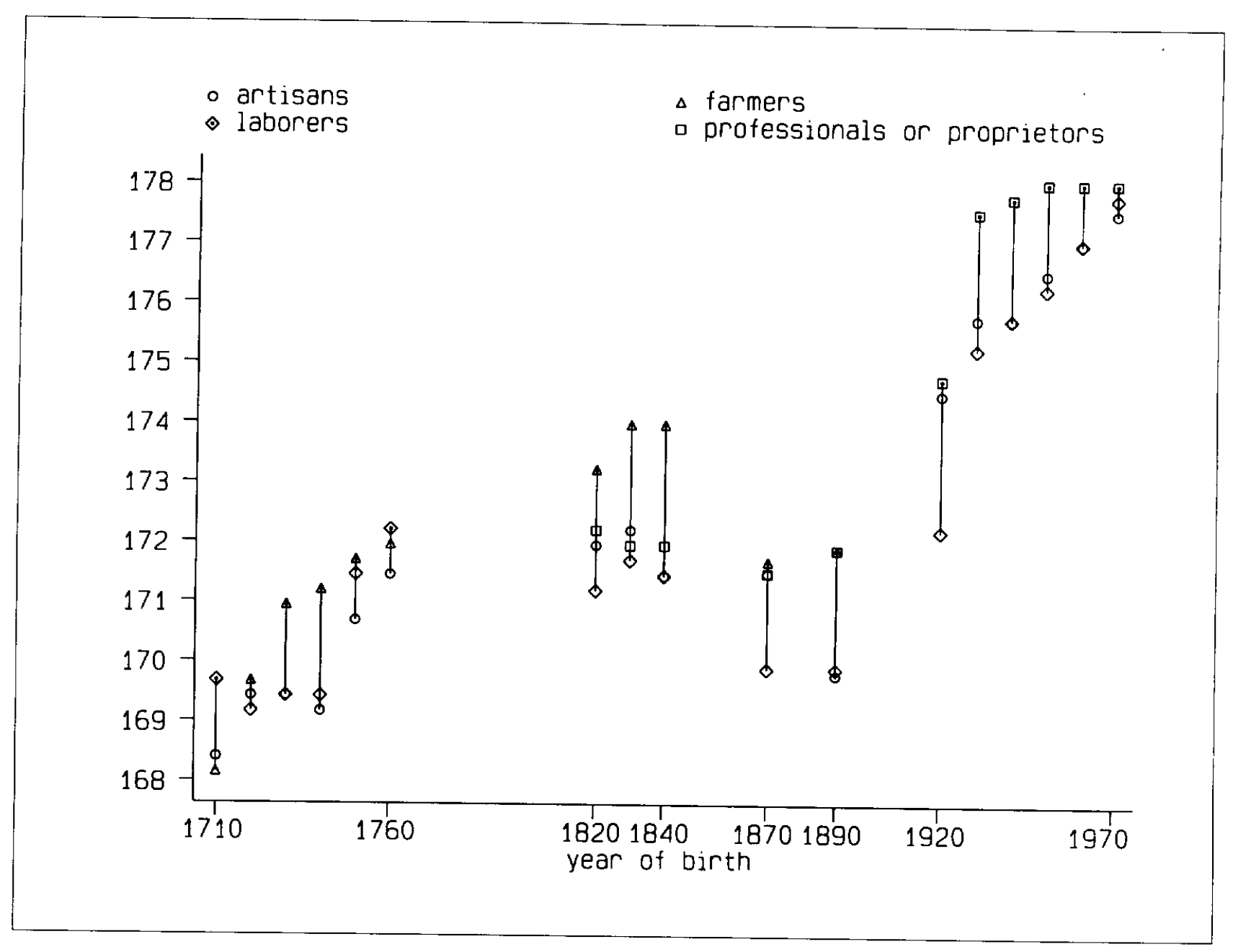

Note. Year of birth is centered at the marks. Estimates for 1950-1970 were adjusted to account for biases resulting from self-reporting in the 1991 and 1981 NHIS. See Figure 1 for sources. 
cupational class narrowed from the cohort that was born in 1705-1714 to that born in 1745-1754 and 1755-1764 and then rose again to reach relatively high levels for the cohort that served in the Civil War. ${ }^{9}$ Height differentials by occupational class did not substantially narrow until the cohort born in 1935-1945. Evidence from the Ohio National Guard suggests that the range in heights was over two centimeters in the latter half of the nineteenth century (Steckel and Haurin 1982). Similarly BMI differentials were greater during the Civil War and at the turn of the century than in more recent years (see Figure 4).

Another way to examine the distribution of health is by looking at height and BMI differentials by race. Height differentials by race appear to have increased sharply from the cohorts born in 1815-1824 and 1825-1834 to those born in 1835-1845. Differentials among cohorts born in 1935-1945 and later were smaller than those among cohorts born in the two earlier decades (see Figure 5). Less is known about BMI. Fogel (1989) reports that the mean BMI of runaway adult male slaves treated as contraband of war by a Mississippi field commander was 24.3, far greater than the mean BMI of 22.2 of Uniun Army soldiers. However by World War II differences in BMI by race among men were insignificant and have remained so to this day.

Differences in rural and urban areas deserve mention as well. Most of the nineteenth century height decline occurred within the rural population. Soldiers who were born in urban areas of 10,000 or more people were approximately 3.3 centimeters shorter than farmers (Margo and Steckel 1983). Since the share of the U.S. population living in places of 10,000 or more increased from 6 percent in 1830 to 14.8 percent in 1860 , urbanization could explain only 0.29 $(=0.088 \times 3.3)$ centimeters of the height decline that was approximately 2.5 centimeters between 1830 and 1860 . We note, however, that urbanization may have played a supporting role in the continuing height decline since evidence from the Ohio National Guard shows a modest height

\footnotetext{
${ }^{9}$ Sokoloff and Villaflor (1982) noted this widening of height differentials by occupational class from the cohort that served in the American Revolutionary War to the cohort that served from 1815 to 1820 .
} 
Figure 4: Mean BMI Differentials by Age and Year, 1863-1991

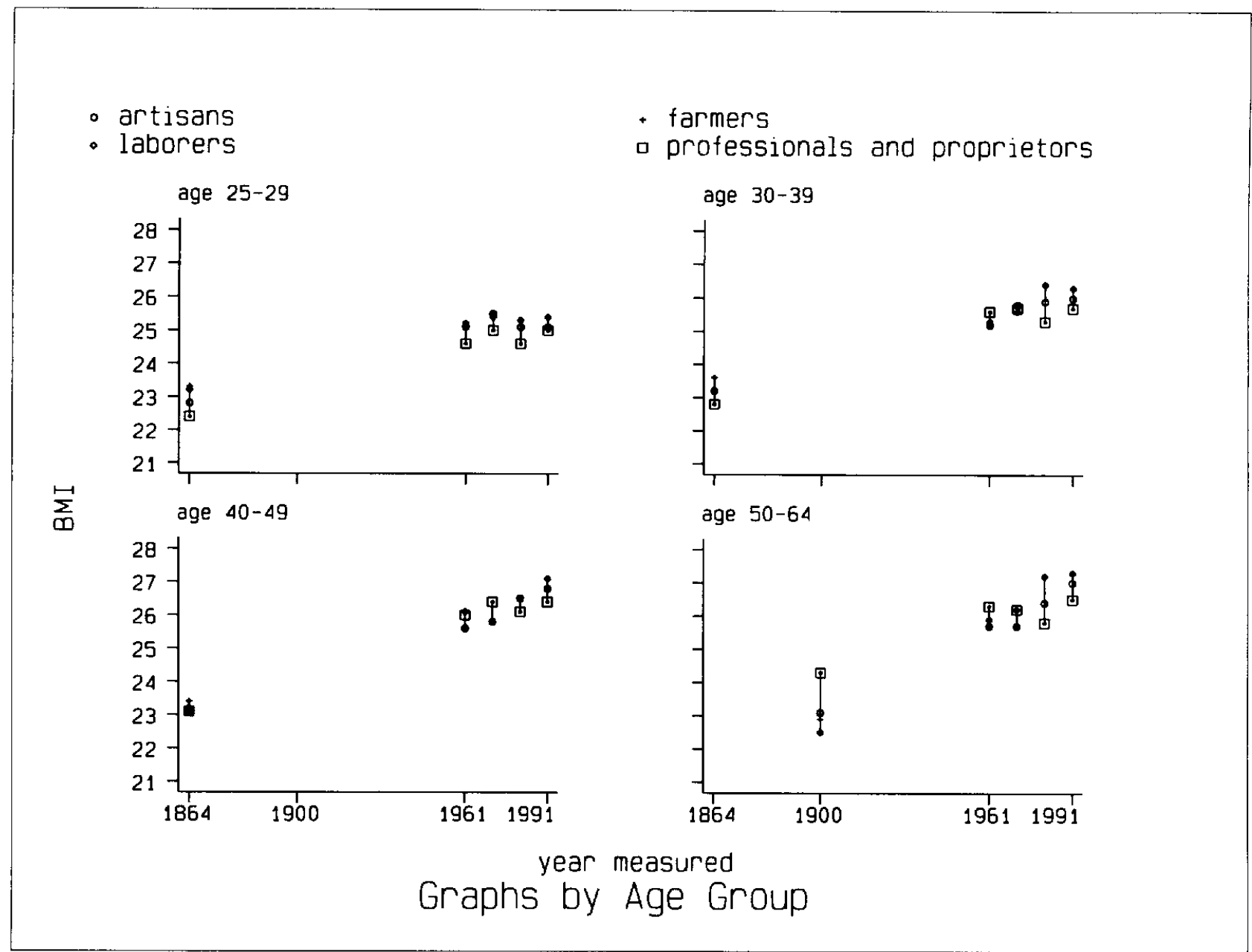

Note. Year of birth is centered at the marks. The means for 1950-1970 were adjusted to account for biases in self-reported heights in the NHIS. See Figure 2 for sources. 
Figure 5: Mean Adult Height Differentials by Race and Birth Cohort, 1820-1970

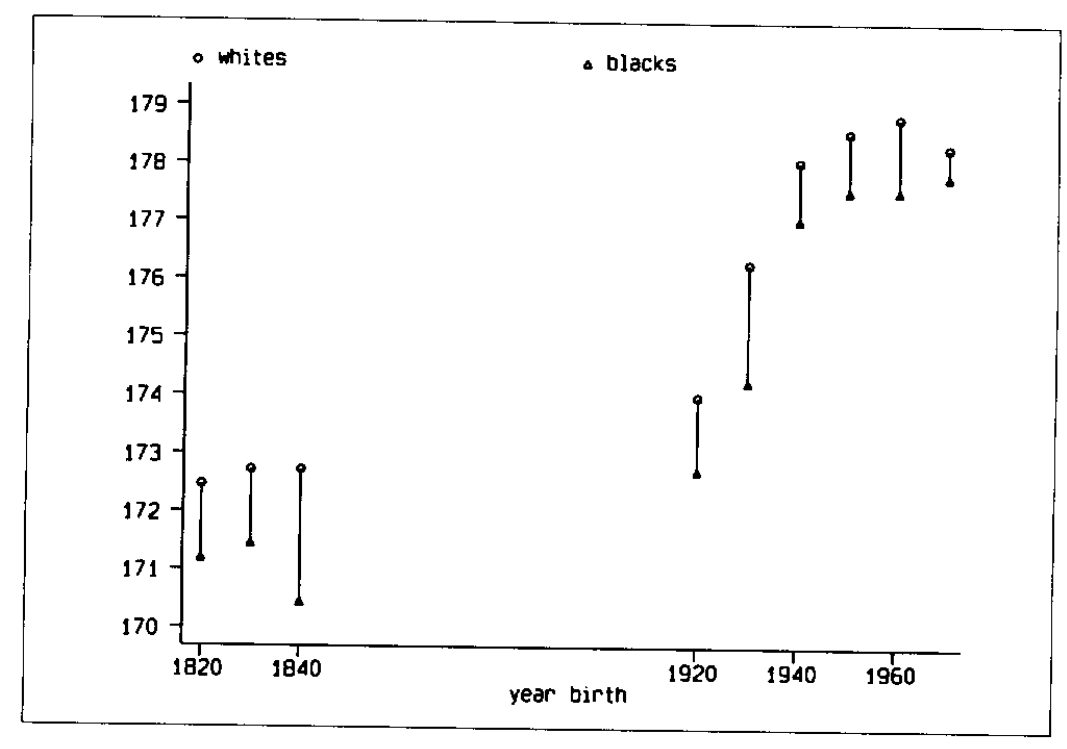

Note. The data have not been adjusted to reflect self-reporting biases in height in the 1981 and 1991 NHIS. Data come from Union Army Recruits in White Regiments in the United States, 1861-1865, Union Army Recruits in Black Regiments in the United States, 1862-1865, Karpinos (1958), 1959-1962 NHES, 1971 NHANES, and 1991 NHIS.

decline in large cities later in the century. Compared with those born before 1880, the heights of those Ohio National Guard troops born from 1880-1896 were 2.3 centimeters less among residents in cities of 50,000 or more. The share of the population living in cities of 50,000 or more residents increased from 12.7 percent in 1870 to 22.3 percent in 1900. There are still some differences in average heights today by extent of urbanization of place of residence among white, native-born men aged 18-19, but the differences are much smaller than in the past. In the 1991 National Health Interview Survey, men in central city metropolitan statistical areas were about $1 \mathrm{~cm}$ shorter than their counterparts in non-central city metropolitan statistical areas and in non-farm areas that were not metropolitan stastical areas. 


\section{Explaining Trends in Health}

What is striking about the trend in health is both the dramatic improvement witnessed in the twentieth century and the decline in health during the middle of the nineteenth century at a time of rising incomes. The twentieth century trends suggest that health and income should be positively associated. Numerous studies on modern data show a positive association between health and socioeconomic status. In the absence of evidence to the contrary, economic historians tend to assume that relationships established on modern evidence also hold for the past. Indeed, an important thrust of the profession has been to elucidate the continuity of economic behavior and to demonstrate the relevance of the past for understanding the present.

We begin by noting that low or negative time-series correlation between income or real wages and mortality rates have been reported for historical data in counties such as England and Italy (Livi-Bacci 1991; Kunitz and Engerman 1993). Among groups that in the United States have been studied at the individual level, the relationship between wealth and survival rates suggests a more egalitarian pattern of death. Wealth conveyed no systematic advantage for survival of women and children in households matched in the 1850 and 1860 censuses (Steckel 19o8; Davin 1993). Preston and Haines (1991) report that place of residence and race were the most important correlates of child survival in the late nineteenth century. Although Costa (1993a) finds that gains in height from wealth were significant in the East, they were negligible in the West. The work of Lee (1995) provides an explanation. He finds that among recruits inducted into the Union Army army, the probability of dying of illness while in the service was not related to wealth, but the

probability of dying from a disease with a nutritional basis was strongly and significantly related to wealth. What his findings suggest is that it is hard to identify the effect of wealth under a very severe disease environment in which acute infectious diseases are prevailing. The effects of other factors, such as the difference in immunity status or rates of exposure to disease may dominate 
the effect of wealth.

Support for this view is provided by the seemingly weak association in the Union States between individual heights and access to resources. Support for a strong relationship comes from the finding that occupational differences in stature among Europeans amounted to several centimeters (Komlos 1990; Floud et al. 1990). On the streets the nobility were easily distinguishable from the poor by their greater height, bulk, and fine clothing. Yet, the variation in average heights across the range of occupations in America was much smaller, usually less than two or three centimeters in the middle of the nineteenth century and nearly nonexistant in the eighteenth, which suggests that class differences in health were small; even the poor may have been well fed in the United States and place of residence appears to have been more important than wealth (Sokoloff and Villaflor 1982; Margo and Steckel 1983).

One of the plausible explanations for the nineteenth century decline and twentieth century improvement in health therefore emphasizes the consequences of greater exposure to infectious diseases. Infections such as rubella, hepatitis, cytomegalovirus, and toxoplasmosis in the mother can lead to damage in developing fetal organs and tissues including the myocardium, skeletal muscle, the inner ear, the optical lens and nerve, the teeth, the liver, and the brain. Damage to fetal organs also may arise from the ingestion of toxic substances by the mother and maternal chronic conditions, such as rheumatic heart disease. During early infancy, when the growth and expansion of the alveoli is still being completed, a respiratory infection will retard infant growth and lead to worsened lung capacity at late adult ages, a condition associated with both respiratory disorders and heart disease. In fact, the geographical distribution of ischaemic heart disease in Great Britain correlates more closely with past infant respiratory mortality than with other leading causes of neo-natal disease (Barker 1992).

At later childhood ages, repeated exposure to infectious disease will lead to growth retardation. Whitehead (1977) concludes from work in developing countries that although children 
are capable of very rapid growth rates when they wie not suffering from disease and when they have sufficient food to support catch-up growth, the high rates of infection lead to low average growth rates. Many studies find a significant relationship between growth retardation and the incidence of diarrhea, but not of respiratory infections (Martorell and Habicht 1986). At adult ages repeated exposure to infectious disease will lead to wasting. The high levels of chronic diarrhea seen in Table 3 among Union Army veterans are likely to have resulted in low BMIs. Other chronic diseases may well play a role. Chronic respiratory disorders show a U-shaped relation to BMI (Roman Diaz 1992; Makela et al. 1991; Negri et al. 1988). The incidence of pulmonary tuberculosis is greater at lower BMI levels (Tverdal 1988).

The nineteenth century decline in health may be explained by the greater exposure to infectious disease brought on by higher rates of interregional trade, migration, and immigration, and by the push of midwestern farming into marshy and river-bottom lands that hosted malaria. Migration and trade may increase morbidity and mortality by spreading communicable diseases and by exposing newcomers to different disease environments (Smillie 1955; May 1958; Curtin 1989). These adverse consequences could have been substantial before public health measures became effective. Indeed, prior to the late nineteenth century isolated, pre-industrial populations in sparsely settled regions were often relatively tall, as discovered in Ireland, the interior of the American South, Austria-Hungary, Sweden, and Japan (Sandberg and Steckel 1987; Shay 1986; Komlos 1989; Nicholas and Steckel 1992; Margo and Steckel 1982 and 1992).

In the twentieth century, exposure to infectious disease may have been lessened by the investments in public health made between 1870 and 1930 , such as the cleaning of the water supply, the establishment of sewage facilities, the development of effective systems of quarantine, the cleaning of the milk supply, and the clearing of slums. Condran and Cheney (1982) found that in Philadelphia during 1870-1930 the spread of knowledge about the environmental sources of disease and the isolation of carriers of disease were extremely effective in reducing mortality rates. 
The importance of improvements in sanitation is suggested by the finding of Preston and Haines (1991) that by 1900 the largest cities were not the most lethal. However, with the exception of the top ten cities, mortality did rise with city size. The importance of exposure to infectious disease is also suggested by Higgs' (1979) finding that in large cities towards the end of the nineteenth century, the death rate varied positively with immigration rates into the city.

A second line of research aimed at explaining the nineteenth century decline in heights emphasizes the sensitivity of average heights to the distribution of income or wealth. Based on regressions on height from twentieth century data, a rise of 0.17 in the Gini coefficient would have offset the rise in per capita income and account for a 4 centimeter decline in average stature (Steckel 1995). The modest evidence on inequality trends in the U.S. has evoked controversy, but it seems plausible that growth in inequality could have contributed significantly to the secular decline in stature. The Gini coefficient on taxable wealth in Massachusetts increased from 0.734 in 1820 to 0.907 in 1900 and in Ohio it rose from 0.806 in 1830 to 0.864 in 1900 (Steckel 1994).

Yet another explanation for the height decline is provided by Komlos (1987) who argues that the height decline may have been caused by a deterioration in the diet created by the sectoral shift in production that occurred during industrialization. According to this view, urbanization and the expansion of the industrial labor force increased the demand for food while productivity per worker and the agricultural labor force grew slowly, causing a decline in food production (especially meat) per capita. A decline in per capita meat consumption could lead to maternal malnutrition and anemia and therefore to fetal malnutrition.

Changes in labor organization that led to greater exposure to disease in the work place in the nineteenth century also deserve attention in a list of potential explanations for the midnineteenth century decline in health. The home manufacturing typical of the eighteenth century diffused geographic patterns of work and insulated the population from contagious disease. In contrast, factories and artisan establishments that emerged in the 1820 s and 1830 s concentrated 
employees in the work place under conditions that increased the risk of exposure to infectious diseases. Numerous people crowded in dusty or humid environments, typical of textile mills, led to the spread of tuberculosis and pulmonary illnesses. These conditions are important for understanding the secular decline in stature of the mid-nineteenth century because children comprised a substantial share of the labor force during America's industrial revolution (Goldin and Sokoloff 1982). The geographic spread of industrialization to the Midwest widened the scope of this claim on nutrition.

Despite improvements in working conditions at the beginning of the twentieth century such as the decline in hours of work, especially those of women and children, occupational health hazards remained high in the first third of the century in part because few safety precautions were taken. The adverse health consequences of employment in most manufacturing, extractive, and agricultural occupations were well recognized by insurance companies, industrial physicians, directors of compensation boards, factory inspectors, and general practitioners of medicine and lists of hazardous occupations were compiled (e.g. Britten and Thompson 1926). Among the hazards were extreme dry heat such as that found in foundry work, sudden variations in temperature, dampness, organic and inorganic dust, infections from the handling of animal products, and exposure to infected soil and to poisons used in the manufacturing process. Increased safety precautions in manufacturing, the shift of women into the clerical sector, and the more recent shift of male employment into the service sector have reduced exposure to hazardous working conditions.

Advances in medical technology also must be credited with improving quality of life in the latter half of the twentieth century. Table 3 showed an extremely high prevalence of hernias at the beginning of the century when they were still untreatable. Among Union Army veterans age 65 and over in 1910 , the prevalence of hernias was $35 \%$, but it was only $7 \%$ among WWII veterans of the same age in 1985-1988. However, $27 \%$ of veterans of the same age in 1983 had 
ever had a hernia, suggesting that most of the improvement in prevalence rates for hernias has come from medical advances (Fogel et al. 1994).

A major therapeutic advance has been the introduction of antibiotics. Infectious diseases in infancy and early childhood can now be cured before they lead to large reductions in the rate of growth and damage to developing organs. In fact, the introduction of antibiotics between 1930 and 1950 coincides with a rapid increase in height. ${ }^{10}$ The cohorts that were born in the age of antibiotics have not yet reached age 65 . They will not reach age 90 for another quarter of a century. As pointed out by Preston (1993), those who are now 90 were born in 1905 when life expectancy at birth was only 50 years, 12 out of one hundred children did not survive infancy, and the burden of infectious diseases was exceptionally heavy. Nonetheless, they were born at a time when life expectancy at birth had improved. In fact, improvements in the disease environment that resulted in the development of better physiques and less scarring by the sequelae of infectious disease may explain the increase in the size of the "old-old" population since the 1970s. Continued improvements in the disease environment are likely to lead to futher increases in the size of the "old-old" population. Social Security Administration projections are based upon the percentage decline over the last ten to fifteen years. Past projections have failed to anticipate improvements in mortality (Crimmins 1984). The marked improvement in stature between 1930 and 1950 suggests that projections based upon recent mortality declines are likely to be off the mark once more.

\section{Welfare}

Since health is a major component of human welfare, it is important to know whether traditional measures of the standard of living, such as per capita income, adequately incorporate the value

\footnotetext{
${ }^{10}$ The increase in heights also coincides with the first period in which public health investments were fully in place.
} 
of health status. The measurement problem is diminished to the extent that measured incomes are spent to improve health. For example, if households spend additional income on a better diet, the health benefits of these expenditures are reflected in a higher GNP. Similarly, outlays on medical equipment are incorporated in the same way as purchases of other consumer products that increase satisfaction. The issue is whether traditional measures of the standard of living, such as per capita income, are overshadowed by the consumer surplus of these expenditures.

The decline in health of the mid-nineteenth century occurred despite income growth. Although it is conceivable this happened by shifting income away from health-producing products such as diet and housing, the explanations discussed earlier suggest that the decline in health was largely independent of consumer expenditures. Of course, the same cannot be said of the connection between income growth and improvement in health that took place late in the century.

If changes in income per capita inadequately reflect changes in welfare, it is important to consider methodologies for appraising welfare change. Although it is possible to show that for any social well-being function, there is a corresponding formulation of real national income, which, if used would reflect what is claimed of it (Dasgupta 1993), in practice such a formulation cannot be computed. The prices that would be used for computing an ideal national income index are shadow prices, not market prices. Furthermore, a number of the components of an ideal index remain unrecorded, such as the social worth of commodities that enhance health.

Below we compare the results of alternative methodologies for appraising welfare change based on techniques used in the economics literature. Because each method in use has shortcomings, here we are unable to provide quantitative estimates of welfare change that are definitive or convincing. Nevertheless, the pattern of results establish the importance of including health in our conceptual apparatus for the standard of living, and suggest that the course of welfare in the middle of the nineteenth century diverged importantly from that indicated by per capita income alone. 
An early exploration of computable ways of improving upon estimates of real national income as measures of well-being is represented by the work of Usher (1973 and 1980). Usher used age specific mortality rates and their shadow prices to calculate willingness to pay for an improvement in the chances of survival. The fairly strong assumptions that he needed to make about utility functions were 1$)$ that utility, $U_{t}$, is : function of consumption, $\left({ }_{t}\right.$, in each time period, $t$; 2) that utility is separable in $C_{t}$; 3) that all utility functions take the special form $U_{t}=\sum_{i=0}^{t-1} C_{i}^{\beta} /(1+r)^{i}$ where $\beta$ is the elasticity of annual utility with respect to consumption and $r$ is the subjective rate of discount; and 4) that consumption is constant across all ages. He then calculated willingness to pay for an improvement in the chances of survival as

$$
\frac{1}{\beta} C_{0}\left[\sum_{j=0}^{n} \frac{S_{j}}{(1+r)^{j}}\right]
$$

where $S_{t}$ is the probability of surviving to year $t$ and is equal to $\prod_{j=0}^{t-1}\left(1-D_{j}\right)$ where $D_{t}$ is the mortality rate $t$ years from the individual's current age. Usher then defines $\hat{C}(t)$ to be the level of consumption at which one would be as well off with the mortality rates of some base year, $T$, as one was with the actual consumption level, $C(t)$, and mortality rates of that year. That is,

$$
\hat{C}(t)=C(t)[L(t) / L(T)]^{\frac{1}{3}}
$$

where $L(t)$ is an index of mortality (or survival) rates capturing life expectancy effects and is defined as $L(t)=\sum_{j=0}^{n} \frac{s_{j+1}(t)}{(1+r)^{3}}$. The impact of improvements in mortality over time is then measured by the difference between the growth of $\hat{C}(t)$ and $C(t)$, or

$$
G_{\hat{C}}=G_{C}+\frac{1}{\beta} G_{L}
$$

Usher's approach can therefore be implemented from a time series of real net national income per 
Table 4: Measured and Revised Real Per Capita GNP in 1958 Dollars

\begin{tabular}{|r|r|rr|rr|}
\hline & & \multicolumn{2}{|c|}{$\mathrm{r}=0.05$} & \multicolumn{2}{|c|}{$\mathrm{r}=0.10$} \\
\hline \multicolumn{1}{|c|}{ year } & actual & $\beta=0.25$ & $\beta=0.45$ & $\beta=0.25$ & $\beta=0.45$ \\
\hline \hline 1849 & 254 & 62 & 116 & 96 & 148 \\
1859 & 300 & 90 & 154 & 132 & 190 \\
$1869-1878$ & 531 & 187 & 298 & 258 & 356 \\
$1879-1888$ & 774 & 209 & 374 & 313 & 468 \\
1890 & 836 & 292 & 466 & 411 & 564 \\
1900 & 1011 & 387 & 593 & 537 & 711 \\
1910 & 1299 & 634 & 872 & 776 & 975 \\
1920 & 1315 & 683 & 914 & 819 & 1011 \\
1930 & 1490 & 1079 & 1245 & 1198 & 1320 \\
1940 & 1720 & 1720 & 1720 & 1720 & 1720 \\
1950 & 2342 & 3150 & 2761 & 2771 & 2572 \\
1960 & 2699 & 4007 & 3362 & 3356 & 3046 \\
\hline \hline
\end{tabular}

Note. Decadal averages were used for the years 1869-1878 and 1879-1888 (Gallman 1966; Series F-4 in U.S. Bureau of the Census). Lifetables for 1870 and 1880, respectively, were used for these years (Haines 1994).

head and age-specific mortality rates.

Age-specific mortality rates at 10 year age intervals are available for 1850 onwards (Haines 1994; Preston et al. 1972). These indicate that from 1850 to 1860 and from 1860 to 1870 mortality decreased and then increased in 1880, almost reaching the level prevailing in 1850 . After 1880 there was a sustained decrease in mortality rates. What this mortality pattern suggests is that real per capita GNP will overestimate the increase in well-being from 1870 to 1880 and underestimate the increase in well-being after 1880. Table 4 shows actual real per capita GNP and revised GNP estimates under various assumptions about the interest rate, $r$, and the elasticity of annual utility with respect to consumption, $\beta$. The base year is 1940 . The parameters were chosen solely to give an indication of the variation in the resulting estimates. Actual and revised decadal growth rates of real per capita GNP are given in Table 5. These indicate that conventional estimates of the growth rates of per capita GNP overestimate well-being by 30 to 75 percent 
Table 5: Measured and Revised Decadal Growth Rates (in Percentages) of Per Capita GNP

\begin{tabular}{|r|r|rr|rr|}
\hline & & \multicolumn{2}{|c|}{$\mathrm{r}=0.05$} & \multicolumn{2}{|c|}{$\mathrm{r}=0.10$} \\
\hline years & actual & $\beta=0.25$ & $\beta=0.45$ & $\beta=0.25$ & $\beta=0.45$ \\
\hline \hline $1849-1859$ & 18.1 & 45.2 & 32.8 & 37.5 & 28.4 \\
$1859-(1869-1878)$ & 77.8 & 107.8 & 93.5 & 95.5 & 87.4 \\
$(1869-1878)-(1879-1888)$ & 46.0 & 11.8 & 25.5 & 21.3 & 31.5 \\
$(1879-1888)-1890$ & 8.0 & 83.0 & 24.6 & 31.3 & 20.5 \\
$1890-1900$ & 20.9 & 32.3 & 27.3 & 30.7 & 26.1 \\
$1900-1910$ & 28.5 & 63.8 & 47.0 & 44.5 & 37.1 \\
$1910-1920$ & 1.2 & 7.7 & 4.8 & 5.5 & 3.7 \\
$1920-1930$ & 13.3 & 58.0 & 36.2 & 46.3 & 30.6 \\
$1930-1940$ & 15.4 & 59.0 & 38.2 & 43.6 & 30.3 \\
$1940-1950$ & 36.2 & 83.1 & 60.5 & 61.1 & 49.5 \\
$1950-1960$ & 15.2 & 27.2 & 21.8 & 21.1 & 18.4 \\
\hline
\end{tabular}

Note. See the footnotes to Table 4.

during the increases in mortality from the 1870 s to the 1880 s and underestimate increases during other time periods. The underestimates are up to 530 percent (1910-1920).

The extent of variation seen in the revised GNP estimates under different assumptions about the interest rate and the elasticity of annual utility with respect to consumption suggests that assessments of the exact dollar value of improvements in longevity can easily be disputed. Another potential problem is the treatment of longevity gains as exogenous. If measured consumption includes investments in health that influenced longevity, then there will be double counting (Williamson 1984). This is especially likely to be a problem during the latter half of the twentieth century when medical technology advanced to a level high enough to allow effective cures.

Another problem is that Usher's calculation only accounts for the impact of longevity and not that of health. Consider the following calculation. A way to estimate willingness to pay to achieve modern BMIs is to estimate the present value of lost income as a result of lowered participation. A lower bound estimate of the present value of lost income is simply discounted earnings times the probability of non-participation. An increase in mean BMI from 23.0 to 26.4 
among Union Army veterans suggests that the probability of labor force non-participation should fall by 6 percent. Then, accounting for the decreased mortality risk, assuming an interest rate of $5 \%$, and assuming that life ends at age 80, a man age 50 in 1900 should be willing to pay about $9 \%$ of the average annual earnings of a manufacturing worker to increase his BMI from the mean in $1^{090}$ to the mean in 1990 . Note that $a^{1+h o u g h}$ in this calculation the present value of lost income is interpreted as the morbidity cost of a low BMI, we could also interpret the present value of lost income as willingness to pay for a reduction in mortality under the assumption that utility is strictly equal to income. The much lower estimate of the value of life that results from this interpretation suggests that equating utility with income provides an extreme lower bound of willingness to pay for a reduction in mortality. ${ }^{~ " ~}$

An alternative approach to the direct valuation of improvements in longevity was that taken by Morris (1979) who used a weighted sum of life expectancy at birth, the infant survival rate, and the adult literacy rate. The UNDP's (1990) Human Development Index (HDI) builds upon the work of Morris. The HDI is simply the sum of normalized indices of per capita national income, life expectancy at birth, and the adult literacy rate. Comparisons can be made across a set of countries by determining maximum and minimum values for each of the indicators: life expectancy $\left(X_{1}\right)$, literacy $\left(X_{2}\right)$, and the log of real GDP per capita $\left(X_{3}\right)$. A deprivation measure places a country on a scale of zero to one as specified by the difference between the maximum and minimum values. Specifically, $I_{i j}$ is the deprivation indicator for country $j$ with respect to indicator $i$, where $I_{i j}=\left(\max X_{i j}-X_{i j}\right) /\left(\max X_{i j}-\min X_{i j}\right)$, and the average level of deprivation for country $j$ is given by $I_{j}=\left(I_{1}+I_{2}+I_{3}\right) / 3$. The Human Development Index for country $j$ is defined as one minus the average deprivation index: $(H D I)_{j}=\left(1-I_{j}\right)$.

The index immediately attracted attention and scrutiny, and a recent survey addresses

\footnotetext{
${ }^{11}$ Rosen (1988) points out that using the present value of lost income as an estimate of the value of life is unjustifiable from utility theory.
} 
several concerns including the number of dimensions, the choice of indicators, weights, and the selection of minimum and maximum values (United Nations 1993: 104-14). The HDI measures relative progress on a scale of basic or minimal measures, and as the quality of life in a country improves, additional attributes or dimensions become important in distinguishing levels of welfare Of particular concern for work in economic history are the choice of indicators and the selection of maximum and minimum values. Lack of data may constrain the choice of indicators and the maximum and minimum values should be wide enough to encompass a broad range of historical experience.

Since a consistent series on life expectancy is unavailable for the United States in the early nineteenth century, we chose stature as our basic measure of health. ${ }^{12}$ Indeed, as a measure of net nutrition, height is a good alternative since it is sensitive to the consumption of basic necessities and to disease that absorbs or diverts nutritional intake. We are aware that use of stature as a health indicator gives a somewhat different meaning to the HDI since height emphasizes conditions in childhood as opposed to the entire life span captured by life expectancy at birth. Moreover, life expectancy at birth is a cross- section measure of health, whereas the data on stature are arranged by birth cohort. ${ }^{13}$

In order to place our HDI in a broad historical context, we chose zero and 100 per cent as the minimum and maximum for literacy rates, and our range for stature of adult men adopts the height of the Bundi of New Guinea as the minimum $(156 \mathrm{~cm})$ and the upper end is defined by the current tallest national population, which is approximately $180 \mathrm{~cm}$ (Eveleth and Tanner, 1990).

\footnotetext{
${ }^{12}$ Our estimates of stature are derived from Figure 1, using linear interpolation where necessary. Where gaps appear in the national height series in the late nineteenth century, we used interpolation based on the Ohio National Guard under the assumption that the national time pattern followed that in Ohio (see data reported in Steckel 1992: 288).

${ }^{13}$ Specifically, our HDI mixes cross-section and cohort indicators whereas the UN's HDI uses cross-section measures only. In principle, could place stature on a cross-section basis by calculating the average height of those who were alive in a particular year, an approach complicated by lack of information on deaths.
} 
Table 6: Human Development Index (HDI) and Components, 1800-1970

\begin{tabular}{|l|r|rrr|}
\hline year & HDI & Income/ & Literacy & Height \\
\hline \hline 1800 & 0.577 & 302 & 0.724 & 172.9 \\
1810 & 0.586 & 318 & 0.725 & 173.0 \\
1820 & 0.592 & 326 & 0.737 & 172.9 \\
1830 & 0.612 & 349 & 0.745 & 173.5 \\
1840 & 0.614 & 391 & 0.761 & 172.2 \\
1850 & 0.618 & 430 & 0.780 & 171.1 \\
1860 & 0.644 & 523 & 0.803 & 170.6 \\
1870 & 0.682 & 659 & 0.800 & 171.2 \\
1880 & 0.711 & 909 & 0.830 & 169.5 \\
1890 & 0.744 & 1113 & 0.867 & 169.1 \\
1900 & 0.795 & 1395 & 0.893 & 170.0 \\
1910 & 0.864 & 1747 & 0.923 & 172.1 \\
1920 & 0.884 & 1743 & 0.940 & 173.1 \\
1930 & 0.894 & 2025 & 0.957 & 173.4 \\
1940 & 0.926 & 2370 & 0.971 & 176.1 \\
1950 & 0.951 & 3133 & 0.974 & 177.1 \\
1960 & 0.955 & 3623 & 0.978 & 177.3 \\
1970 & 0.962 & 4774 & 0.990 & 177.5 \\
\hline \hline
\end{tabular}

Note. Compiled from the sources cited in the notes to Figure 1, Weiss (1992), U.S. Bureau of the Census (1975), and the Public Use Sample of the 1850 Census. See the notes to the text for more details.

The price of a subsistence diet, $\$ 140$ in 1970 dollars, is our minimum for per capita income, and we take the UN's upper bound of $\$ 4,861$ (1855 \$) as our maximum (see the Introduction to this volume).

The results displayed in Table 6 give perspective to welfare during industrialization. We first note that the level of the index is quite high on the eve of industrialization despite the poverty (as measured by per capita income) of the era. Americans were reasonably well off as measured by the HDI - certainly much better off than the residents of poor developing countries 
of the late twentieth century. ${ }^{14}$ Despite low incomes, stature was relatively high and a substantial majority of the population was literate (note that the literacy rate includes slaves, who we assume were illiterate)..$^{15}$

Second, the years after 1830 are often glorified by economic historians as signifying the onset of industrialization and improving living standards, yet our measure of the HDI indicates that welfare essentially stagnated during the early phase of industrialization. The stagnation occurred because modest increases in per capita income and literacy were offset by declines in stature. Although stature declined after 1860, reaching a low point in 1890, the HDI increased substantially in the closing decades of the nineteenth century because literacy improved moderately (largely through education of blacks) and there were large absolute increases in per capita income.

It may seem difficult to reconcile welfare declines with early industrialization, but an important point often overlooked is that the base from which gains were made was very low in the early industrial period. Put another way, the HDI increased more in the last three decades than it did in the first 70 years of the century. Growth rates at newly high (modern or near modern levels) were impressive, and though they deserve our adulation and study as a significant departure from

\footnotetext{
${ }^{14}$ The ten worst countries on the scale of Human Development had an average HDI of 0.172 in 1987 (United Nations 1990: 128-129). The index we tabulated for the U.S. is not quite comparable, however, because the measure of health is different and the minimia and maxima for the other indicators also differ. If we adopt the minima and maxima for literacy ( 12.3 per cent to 100 per cent) and income ( $\$ 220$ to $\$ 4861)$ used by the UN in 1987 , and if we adjust the income reported for the U.S. in 1970 prices to 1987 levels (\$884), the HDI for the U.S. in 1800 was 0.615 . We note that the high HDI ranking in 1800 exists in part because the U.S. had a lower deprivation ranking using stature as opposed to life expectancy. If we use life expectancy in place of health, invoking a reasonable guess of 45 years, the HDI in 1800 falls to 0.412 , which would achieve a rank of 35th among the list of 130 countries in 1987.

${ }^{15}$ Literacy rates from 1850 onward were taken from the federal censuses as reported in Historical Statistics of the United States. We estimated literacy rates for the free population from 1800 to 1840 using reports of literacy by age contained in the 1850 Public Use Micro Sample (PUMS). We used the literacy of those aged 30 and above in 1850 to estimate literacy in 1840; the literacy of those aged 40 and above in 1850 to estimate literacy in 1830 , etc. We understand this procedure may contain biases to the extent that survival rates varied with literacy. In defense of the procedure, we note that literacy was an impotent predictor of survival of married women from 1850 to 1860 (see Steckel, 1987). The procedure also neglects cohort trends in literacy that may have existed among older generations alive in the early 1800 s who did not survive to 1850 , a defect we cannot remedy. An alternative is to estimate literacy from signature lists available from marriage registers, wills, and other sources, an approach that that involves questions of selectivity, representation by age and region, etc.
} 
the past, the consequences initially took the population only a small way toward modern welfare levels because the absolute gains from these higher growth rates were small enough to be offset by health losses associated with industrialization.

Economic historians must understand that the HDI is a retrospective index of welfare; which asks how and when modern levels of welfare were attained. The early period of industrialization contributed only a tiny absolute portion to welfare levels we now enjoy, but the percentage changes in per capita income it involved were still important for contemporaries. Annual income gains on the order of 1.5 per cent experienced in the second quarter of the nineteenth century were significant, particularly at base levels that were only moderately above subsistence. Thus in terms of measuring progress, there is no inconsistency or contradiction between the HDI and income growth rates, only a difference in perspective. The growth rate is a velocity measure but the HDI is a distance measure, and both are relevant for understanding the past. Growth rates stress changes witnessed by contemporaries, while the HDI measures how far an economy has come along the path to modern living standards. Put differently, the income gains of the first generation of industrial workers, however important to them, amounted to only a pittance compared with income growth experienced by typical modern workers.

A third approach to measuring welfare ranks numerous indicators of the quality of life. Dasgupta (1993) proposes the construction of a ranking based upon six indices - national income, life expectancy at birth, infant mortality rates, adult literacy rates, and two indices of political and civil liberties. Comparisons are then based upon ordinal measures derived from a "Borda" rule. According to the Borda rule each time period is awarded a point equal to its rank within each index (with one representing the lowest rank). The ordinal distance between two time periods depends upon how many time periods squeeze themselves in between for each index that is studied. The rankings are then summed across all indices to construct a Borda rank. The use of this methodology for comparing developing countries in the 1980 s yields reasonable results 
Table 7: Rankings of Living Standards Data by Year, 1849-1970

\begin{tabular}{|r|r|rrrrr|}
\hline \multicolumn{1}{|c|}{ year } & $\begin{array}{c}\text { Borda } \\
\text { rank }\end{array}$ & GNP/N & $\begin{array}{c}\text { infant } \\
\text { mortality }\end{array}$ & $\epsilon_{0}$ & $\begin{array}{c}\text { school } \\
\text { enrollment }\end{array}$ & heights \\
\hline \hline 1849 & 1 & 1 & 1 & 1 & 1 & 5 \\
1859 & 2 & 2 & 3 & 3 & 3 & 4 \\
$1869-1878$ & 3 & 3 & 4 & 4 & 2 & 6 \\
$1879-1888$ & 2 & 4 & 2 & 2 & 6 & 1 \\
1890 & 4 & 5 & 5 & 5 & 5 & 2 \\
1900 & 5 & 6 & 6 & 6 & 4 & 3 \\
1910 & 6 & 7 & 7 & 7 & 7 & 7 \\
1920 & 7 & 8 & 8 & 8 & 8 & 8 \\
1930 & 8 & 9 & 9 & 9 & 9 & 9 \\
1940 & 9 & 10 & 10 & 10 & 10 & 10 \\
1950 & 10 & 11 & 11 & 11 & 11 & 12 \\
1960 & 11 & 12 & 12 & 12 & 12 & 11 \\
1970 & 12 & 13 & 13 & 13 & 13 & 13 \\
\hline \hline
\end{tabular}

Note. Decadal averages were used for the years 1869-1878 and 1879-1888(Gallman 1966; Series F-4 in U.S. Bureau of the Census 1975). Lifetables for 1870 and 1880 , respectively, were used for these years. Life tables for 1850-1900 are from Haines (1994) and for 1910-1960 from Preston et al. (1972). School enrollment is from U.S. Bureau of the Census (1975). Heights are from Fogel (1986) and Steckel and Haurin (1982).

(Dasgupta 1993).

We have calculated two indices based upon the Borda rule. The first one is by decade from 1849 to 1970 and has as its component indices real per capita GNP, infant mortality rates, life expectancy at birth $\left(\epsilon_{0}\right)$, school enrollment rates, and average heights for white, native-born men (see Table 7). The second index has as its component indices only real per capita GNP, literacy, and average heights of white, native-born men, but extends back to 1800 (see Table 8). The average height that is used is that for the cohort born near the specified year.

The Borda rankings in Table 7 indicate that well-being fell from 1869-1878 to 18791888 to reach a level comparable to that prevailing in 1859 . After 1888 well-being rose steadily. According to the Borda rankings in Table 8 net welfare was stagnating in the antebellum period. Rankings are high at the end of the nineteenth century because of steady improvements in literacy. 
Table 8: Rankings of Living Standards Data by Year, 1839-1970

\begin{tabular}{|c|c|c|c|c|}
\hline year & $\begin{array}{c}\text { Borda } \\
\text { rank }\end{array}$ & GNP/N & literacy & height \\
\hline 1800 & 1 & 1 & 1 & 10 \\
\hline 1810 & 2 & 2 & 2 & 11 \\
\hline 1820 & 3 & 3 & 3 & 10 \\
\hline 1830 & 6 & 4 & 4 & 13 \\
\hline 1839 & 4 & 5 & 5 & 9 \\
\hline 1844 & 5 & 6 & 6 & 8 \\
\hline 1849 & 5 & 7 & 7 & 6 \\
\hline 1854 & 6 & 8 & 8 & 5 \\
\hline 1859 & 7 & 9 & 9 & 4 \\
\hline $1869-1878$ & 10 & 10 & 10 & 7 \\
\hline $1879-1888$ & 8 & 11 & 11 & 1 \\
\hline 1893 & 9 & 12 & 12 & 2 \\
\hline 1898 & 11 & 13 & 13 & 3 \\
\hline 1903 & 12 & 14 & 14 & 3 \\
\hline 1907 & 13 & 15 & 15 & 8 \\
\hline 1911 & 14 & 17 & 16 & 9 \\
\hline 1916 & 15 & 16 & 17 & 10 \\
\hline 1921 & 16 & 18 & 18 & 12 \\
\hline 1931 & 17 & 19 & 19 & 14 \\
\hline 1940 & 18 & 22 & 21 & 15 \\
\hline 1945 & 19 & 21 & 22 & 17 \\
\hline 1950 & 20 & 21 & 22 & 18 \\
\hline 1955 & 21 & 23 & 23 & 19 \\
\hline 1960 & 21 & 24 & 24 & 17 \\
\hline 1965 & 23 & 25 & 25 & 16 \\
\hline 1970 & 24 & 26 & 26 & 20 \\
\hline
\end{tabular}

Note. Decadal averages were used for the years $1869-$ 1878 and 1879-1888. See Tables 6 and 7 for details on construction. 
When a Borda index constructed only with height and per capita GNP is used, the nadir of wellbeing is reached in 1879-1888 after a pronounced decline from the levels prevailing in 1839 and 1844 and despite a doubling of per capita GNP from 1830 to 1898, net welfare does not improve.

An alternative methodology for appraising welfare changes is to apply the model of Thaler and Rosen (1976) to measure the value of life. In a life cycle model the value of eliminating risk to life at a specific age is the expected value of additional consumer surplus it generates. The value of a current age independent risk can be estimated from equalizing wage differentials on risky jobs. Thaler and Rosen (1976) find that workers in 1967 were willing to pay from 2 to 4 percent of their annual income to reduce death risk from 0.001 per year to 0 . Viscusi (1978) estimates that the risk premium to jobs perceived as dangerous in 1969 was approximately 5 percent of average annual earnings. Although no comparable work has been done for the past, using the Thirteenth Annual Report of the Kansas Bureau of Labor and Industry for 1897 we find that the risk premium for dangerous jobs was about 7 percent. ${ }^{16}$ Assuming that, as a percentage of annual earnings, the risk premium has remained constant over time, we can use Thaler and Rosen's and Viscusi's estimates to derive willingness to pay for a reduction in mortality in the nineteenth century.

In 1850 the probability of a 25 year old man living to age 65 was 0.45 (Haines 1994) and his average height was $171 \mathrm{~cm}$. Had a man in 1850 had the average height of one in $1830(174 \mathrm{~cm})$ he would have experienced a 3 percent fall in mortality. ${ }^{17}$ Had he had the average height of a man in $1890(169 \mathrm{~cm})$ he would have experienced a $6 \%$ increase in mortality. Assuming that the risk premium is 2 to $5 \%$ of average annual earnings, a man in 1850 would have been willing to pay $27-68 \%$ of his annual income to have the height of a man in 1830 . He would have been willing to

\footnotetext{
${ }^{16}$ Estimated from a regression of the wage on worker characteristics and a dummy equal to one if the worker reported being in a dangerous occupation.

${ }^{17}$ Calculated from Waaler's (1984) height-mortality relationship.
} 
give up 54-135\% of his annual income to not have tue height of a man in 1890. Since per capita income increased by $23 \%$ between 1830 and 1850 and by $159 \%$ between 1850 and 1890 , the increase in per capita income between 1830 and 1850 does not outweigh the mortality increase, but it does outweigh the mortality increase between 1850 and 1890. A man in i850 would thus have been wi"'ing to sacrifice increases in mortality for gains in income for the postbellum but not the antebellum period.

\section{Concluding Remarks}

We have presented evidence showing that the course of health and economic growth diverged in the nineteenth century and converged in the twentieth, findings that hold regardless of whether health is measured by stature, BMI, mortality rates, or the prevalence of chronic conditions. In view of the questions posed by these patterns for the adequacy of national accounts as a welfare measure, we quantified the monetary value of changes in life expectancy. Employing several approaches to analyze welfare changes, we estimated a Human Development Index and a Borda Ranking, and we calculated Usher-adjusted incomes and the willingness to pay for a reduction in mortality risk. We found that in the antebellum period the increase in income was insufficient to compensate for the decline in health. The absolute gain in income achieved by modern economic growth in the early industrial period, though important to those alive at the time, was simply too low to offset declines in health. In constrast, improvements in health outpaced economic growth in the twentieth century. Our estimates indicated that whereas real per capita GNP more than doubled between 1900 and 1960, the "true" increase in GNP was six to tenfold.

We argue that changes in the disease environment, among other factors, can partially account for the decrease in well-being in the nineteenth century and the increase in well-being in the twentieth. In the nineteenth century, higher rates of interregional trade, migration, and 
immigration exposed a previously isolated population to disease. Other contributing factors included the rise of public schools, which spread diseases among children; hardships caused by the Civil War; urbanization; growing inequality; and dietary deterioration associated with relatively higher food prices. In the twentieth century, higher incomes combined with growing awareness of expenditures and practices that improved health led to the prevention of disease, while advances in medicine, such as antibiotics and vaccinations, lessened the consequences of exposure to infectious disease. Nutritional status improved in part because public health investments reduced the population's exposure to infectious disease. The full impact of the public health investments made from 1870 to 1930 , such as the establishment of sewage systems and clean water supplies and the cleaning of the milk supply, may not have been manifest for up to 50 or 60 years. Quantification of the impact of changes in the disease environment must await the creation of longitudinal data sets that link early life ecological and environmental variables to subsequent morbidity and mortality. ${ }^{18}$

Our findings suggest that the adverse health consequences noted for the United States in the nineteenth century were significantly a matter of timing. The changes associated with industrialization and modernization occurred before substantial knowledge of effective mechanisms of disease prevention or cure were available. Consequently, the cohorts born before the late nineteenth century bore the scars of infectious disease for the rest of their lives. Later cohorts were more fortunate. By reducing the transmission of disease, public health measures alleviated the effects of urban congestion and of mass migrations. But, the failure of the United States to implement public health measures earlier cannot be blamed upon poor policy decisions.

The new evidence that we presented on trends in health, such as waist-hip ratio, BMI, and the prevalence of chronic conditions at older ages suggested that early life conditions may

\footnotetext{
${ }^{18} \mathrm{~A}$ data set which does this for the cohort born in the 1830 s is currently being created by Fogel et al. A brief description of Early Indicators of Later Work Levels, Disease, and Death is provided in the data appendix.
} 
exert an impact on mortality and morbidity that is not manifest until older ages. The improvement in BMI and the decline in the prevalence of chronic conditions ar older ages were especially striking features of the trend in health. The evidence indicates that a symbiotic relationship existed between disease and BMI: disease increased nutritional status and therefore lowered BMI while a low BMI increased susceptibility to disease. Chronic conditions, and therefore low BMIs, may be linked to malnourishment and exposure to infectious diseases during the fetal and neonatal states, infancy, and early childhood. The waist-hip ratio seen among Union Army soldiers reinforces this hypothesis. A high waist-hip ratio is associated with an increased risk of heart disease and diabetes and is related to markers of maternal and fetal malnutrition. Thus early life conditions may well affect the entire future experience of a cohort.

The rapid increase in stature from the 1930s to the 1950s suggests that the cohorts now approaching their sixties will experience a much greater rate of increase in health and longevity than past generations. Because most recent predictions of the size of the elderly population are based upon the percentage decline in mortality over the last ten to fifteen years, current forecasts are likely to be off the mark. The sensitivity of long-term Social Security balances to uncertainty about the future course of mortality suggests that we can only ignore the evidence from the long-term trend at our peril.

\section{Data Appendix}

The available data sources on height, weight, and other anthropometrics measures and on chronic conditions for the United States include publically available machine readable datasets, machine readable datasets that were not yet publically available at the time of writing, and published sources. The sources that we used in the paper or that were used in papers referred to in the text are described in detail, by category, below. The detailed descriptions give some indication of available variables, manuscript sources, and how to obtain the data. First though, we present the reader with a brief chronological guide to the data sources.

Information on the cohorts born in the early colonial period and in the early republic come from military sources. The anthropometric information that is in these sources is limited to 
height. Although not yet publically available, these sources are in machine readable form and are

- French and Indian War Army Recruits

- American Revolution Army Recruits

- United States Army Recruits, 1815-1820.

The information on nineteenth century cohorts is more extensive and includes not only information on height, but also information on weight and other anthropometric measures and on chronic conditions. Some published information for slaves is available from Richard Steckel's 1979 article listed below. The bulk of the information comes from Civil War records, particularly those of the Union Army. These records include information on blacks, as well as whites. Information from pre-Civil War records comes from the machine readable datasets

- Height and Weight of West Point Cadets, 1843-1894

- United States Army Recruits, 1850-1855.

The first data set is publically available. The second is not.

The publically available, machine readable Civil War records are

- Union Army Ruruis in White Regiments in the United States, 186I-1865

- Union Army Recruits in Black Regiments in the United States, 1862-1865

- Confederate Amnesty Records for the United States Civil War, 1863-1866

- Union Army Slave Appraisal Records from Mississippi, 1863-1865, ICPSR 9427

- Early Indicators of Later Work Levels, Disease, and Death.

All of the datasets contain information on height measured at the time of the Civil War. Union Army Slave Appraisal Records contains information on weight as well. Early Indicators contains information on illnesses incurred while in the service. Although the data in Early Indicators is limited to the Civil War cohort, the sampled Civil War cohort is followed until death and therefore is an excellent source of information on the height, weight, and chronic conditions of the elderly in the first three decades of the twentieth century.

The machine readable Civil War datasets that are not yet publically available are

- Union Army Rejects

- Anthropometric Statistics of Union Army Recruits.

Both data sets contain information on height. The first data set includes causes of rejection as well and the second detailed anthropometric measurements such as weight, waist circumference, hip circumference, shoulder breadth, and dynamometer. Published Civil War sources are 
- Gould, Benjamin Apthorp. 1869.

- Baxter JH. 1875.

Relatively few machine readable sources are available for nineteenth century, postbellum cohorts. With the exception of the already mentioned Height and Weight of West Point Cadets, 1843-1894, the only other source is

- Ohio Nritional Guard

and the anthropometric information in this source is limited to height. Information can, however, be gathered from published sources such as

- United States. Army. Surgeon General.

- Hathaway, Millicent L. and Elsie D. Foard. Human Nutrition Research Division. Agricultural Research Service. United States Department of Agriculture. 1960.

- Davenport, Charles B. and Albert G. Love. Medical Department of the United States Army in the World War. 1921.

- Davenport, Charles B. and Albert G. Love. War Department. 1920.

Information on the twentieth century comes from World War II publications and from the large, machine readable surveys of the entire United States population whose collection began in the late 1950s and early 1960s and continues to the present day. These surveys contain information on height, weight, and chronic conditions and are all publically available. They include

- National Health Examination Survey, Cycle I, 1959-1962

- National Health Interview Survey (NHIS), 1970 to present

- Health and Nutrition Examination Survey (NHANES) I, 1971-1975

- Health and Nutrition Examination Survey (NHANES) II, 1976-1980.

The published World War II sources are

- Karpinos, Bernard D. 1958.

- United States. Selective Service System. 1944.

A detailed description of the data sources is given below. The data sources are in alphabetical order within the three categories of 1) machine readable and publically available, 2) machine readable but not yet publically available, and 3) published sources.

1. Publically available machine readable data sets used in the paper or in papers referred to in text. 
- Confederate Amnesty Records for the United States Civil War, 1863-1866, ICPSR 9429. Principal Investigator: Richard Steckel. Available from:Inter-university Consortium for Political and Social Research, Ann Arbor, MI. Cases: 6,762. Variables: date of amnesty, county and state of amnesty, age, occupation, and height. Original data source: All amnesty oaths signed by persons in the Confederacy and kept in the Diplomacy Branch, Record Group \#59, Entries 466 and 467 in the National Archives.

- Early Indicators of Later Work Levels, Disease, and Death. Principal Investigators: Rotert W. Fogel et al. A subsample of this data set had been released to InterUniversity Consortium for Political and Social Research, Ann Arbor, MI as The Aging of Veterans of the Union Army. Additional data will be released as it becomes available. Cases: 39,616. Longitudinal data set of Union Army recruits linked to 1850, 1860, 1900, and 1910 censuses and military, medical, and pension records, including detailed examinations by examining surgeons. Information is available on morbidity, mortality, height, weight, stresses endured while in service, and socioeconomic and demographic variables, including labor force participation and pension receipiency.

- Health and Nutrition Examination Survey (NHANES) I, 1971-1975 Principal Investigator: U.S. Department of Health and Human Services, National Center for Health Statistics. Available from: Inter-university Consortium for Political and Social Research, Ann Arbor, MI. Detailed information on specific conditions obtained from clinical exams as well as past medical history. Contains also socio-economic and demographic variables and informationon diet. Information on height, weight, and skinfold measurements is also available. Epidemiological follow-ups are available. Universe: Civilian noninstitutionalized population, aged 1-74, of the United States.

- Health and Nutrition Examination Suney (NHANES) II, 1976-1980 Principal Investigator: U.S. Department of Health and Human Services, National Center for Health Statistics. Available from: Inter-university Consortium for Political and Social Research, Ann Arbor, MI. Similar to NHANES I, with the exception that no epidemiological follow-up is available.

- Height and Weight of West Point Cadets, 1843-1894, ICPSR 9468. Principal Investigators: John Komlos. Available from: Inter-university Consortium for Political and Social Research, Ann Arbor, MI. Cases: 4,178. Variables: age, height, weight, state of birth, state of appointment, date of physical exam, father's occupation and income, and parents' residency.

- National Health Examination Survey, Cycle I, 1959-1962, ICPSR 9203, 9206, 9208, 9209, 9201, 9204, 9207, 9202. Principal Investigator: U.S. Department of Health and Human Services, National Center for Health Statistics. Available from: Interuniversity Consortium for Political and Social Research, Ann Arbor, MI. Cases: 6,672. Variables: physical measurements (including right arm girth, chest girth, waist girth, right arm skinfold, right infrascapular skinfold, height, weight, sitting normal height, sitting erect height, knee height), physician examination and medical history for 
cardiovascular, diabetes, osteoarthritis and rheumatoid arthritis, and vision, and socioeconomic and demographic characteristics. Universe: Civilian, non-institutionalized population aged 18-79 of the coterminous United States.

- National Health Interview Survey (NHIS), 1970 to present. Principal Investigator: U.S. Department of Health and Human Services, National Center for Health Statistics. Available from: Inter-university Consortium for Political and Social Research, Ann Arbor, MI and 1988 to present on CD-ROM from Data Dissemination Branch, National $\mathrm{C}_{i}$ iter for Health Statistics, Centers for Disease Control and Prevention. Yearly survey with questions on chronic impairments, medical care utilization, height, weight, and socio-economic and demographic variables. Each year special supplements include questions on specific topics such as diabetes, smoking, health insurance, exercise, etc. Universe: Civilian, non-institutionalized population of the United States.

- Union Army Recruits in Black Regiments in the United States, 1862-1865, ICPSR 9426. Principal Investigators: Jacob Metzer and Robert A. Margo. Available from: Inter-university Consortium for Political and Social Research, Ann Arbor, MI. Cases: 8,592. Variables: height, age, birthplace, occupation before enlistment, enlistment date, changes in rank.

- Union Army Recruits in White Regiments in the United States, 1861-1865, ICPSR 9425. Principal Investigators: Robert W. Fogel and Stanley L. Engerman et al. Available from: Inter-university Consortium for Political and Social Research, Ann Arbor, MI. Cases: 39,616. Variables: date, place and term of enlistment, place of birth, occupation before enlistment, age at enlistment, height, and county and town latitude and longitude and population figures. Original data source: Union Army muster rolls.

- Union Army Slave Appraisal Records from Mississippi, 1863-1865, ICPSR 9427. Principal Investigator: Robert A. Margo. Available from: Inter-university Consortium for Political and Social Research, Ann Arbor, MI. Cases: 1,213. Variables: age, weight, height, sex, appraised value of slave, and date of appraisal. Original data source: All slaves who appeared in a set of appraisal records for Civil War Mississippi.

2. Machine readable datasets that were not publically available at time writing

- American Revolution Army Recruits. Principal Investigators: Kenneth Sokoloff and Georgia Villaflor. Obtained from: Center for Population Economics, Graduate School of Business, University of Chicago. Cases: 5609. Variables: age, occupation, height; place and date of enlistment, place of birth. Original data source: Army and militia muster rolls.

- Anthropometric Statistics of Union Army Recruits Principal Investigator: Dora L. Costa. The projected release date to Inter-university Consortium for Political and Social Research, Ann Arbor, MI is expected to be the year 2000. Cases: 22,818 (projected). Variables: age, race, occupation, ethnicity, marital status, place of birth, 
place of enlistment, date of examination, date of enlistment, height, height to lower part neck, height to knee, height to perinaeum, waist circumference, hip circumference, chest circumference, breadth neck, breadth shoulders, breadth pelvis, arm length, foot length, weight, chest capacity, condition teeth, condition muscles, pulse rate, respiration rate, dynamometer, whether vaccinated for smallpox, whether athletic before war. Original data source: Records of the United States Sanitary Commission, New York Public Library.

- French and Indian War Army Recruits. Principal Investigators: Kenneth Sokoloff and Georgia Villaflor. Obtained from: Center for Population Economics, Graduate School of Business, University of Chicago. Cases: 9016. Variables: age, occupation, height, place and date of enlistment, place of birth. Original data source: Army and militia muster rolls.

- Ohin National Guard Principal Investigators: Richard Steckel. and Donald Haurin. Obtained from: Richard Steckel. Cases: 5,035 aged 23-49. Variables: name, regiment, company, age, occupation, stature, birthplace, residence, and marital status. Original data source: Ohio National Guard Muster rolls housed in the Ohio Historical Society and the Beightler Armory in Columbus, Ohio.

- Union Army Rejects. Principal Investigator: Richard Steckel. Obtained from: Center for Population Economics, Graduate School of Business, University of Chicago. Cases: 2015. Variables: age, place and date of enlistment, occupation, height, and reason for rejection. Original data source: Union Army rejection records.

- United States Army Recruits, 1815-1820. Principal Investigators: Kenneth Sokoloff and Georgia Villaflor. Obtained from: Center for Population Economics, Graduate School of Business, University of Chicago. Cases: 15,169. Variables: age, height, place and date of enlistment, place of birth. Original data source: Army and militia muster rolls.

- United States Army Recruits, 1850-1855 Principal Investigators: Kenneth Sokoloff and Georgia Villaflor. Obtained from: Center for Population Economics, Graduate School of Business, University of Chicago. Cases: 2497. Variables: age, height, place and date of enlistment, place of birth. Original data source: Army muster rolls.

3. Published sources used in the paper or related to data sets and series used in the paper.

- Baxter JH. 1875. Statistics, medical and anthropological, of the Provost-MarshalGeneral's bureau, derived from records of the examination for military service in the armies of the United States during the late war for the rebellion of over a million recruits of drafted men, substitutes, and enrolled men. Washington, D.C.

- Davenport, Charles B. and Albert G. Love. Medical Department of the United States Army in the World War. 1921. Army Anthropology. Washington: Government Printing Office. 
- Davenport, Charles B. and Albert G. Lovs. War Department. 1920. Defects Found in Drafted Men. Washington: Government Printing Office.

- Gould, Benjamin Apthorp. 1869. Investigations in the Military and Anthropological Statistics of American Soldiers. New York: Published for the United States Sanitary Commission by Hurd and Houghton.

- Hathaway, Millicent L. and Elsie D. Foard. Human Nutrition Research Division. Agricultural Research Service. United States Department of Agriculture. 1960. Heights and Weights of Adults in the United States. Home Economics Research Report No. 10. Washington: Government Printing Office.

- Karpinos, Bernard D. 1958. "Height and Weight of Selective Service Registrants Processed for Military Service During World War II." Human Biology. 30: 292-321.

- Steckel, Richard H. 1979. "Slave Height Profiles from Coastwise Manifests." Explorations in Economic History. 16: 363-380.

- United States. Selective Service System. 1944. Physical Examinations of Selective Service Registrants During Wartime. Medical Statistics Bulletin No. 3. Washington: Government Printing Office.

- United States. Army. Surgeon General. Published Annually. Report of the Surgeon General U.S. Army to the Secretary of War. Washington: Government Printing Office.

\section{References}

[1] Barker, DJP (Ed.). 1992. Fetal and Infant Origins of Adult Disease. London: British Medical Journal.

[2] 1994. Mothers, Babies, and Disease in Laiur Life. London: British Medical Journal.

[3] Bartel A and Taubman P. 1979. "Health and Labor Market Success: The Role of Various Diseases." The Review of Economics and Statistics. 61(1): 1-8.

[4] Behrman, Jere R. and Anil B. Deolaliker. 1989. "Agricultural wages in India: the role of health, nutrition, and seasonality.” In D. Sahn (Ed.), Seasonal Variability in Third World Agriculture. Baltimore, MD: Johns Hopkins University Press.

[5] Blair D, Habicht JP, Sims EAH, et al. 1984. "Evidence for an increased risk of hypertension with centrally located body fat and the effect of race and sex on this risk." American Journal of Epidemiology. 119(4): 526-40.

[6] Britten, Rollo H. and L.R. Thompson. 1926. "A Health Study of Ten Thousand Male Industrial Workers." Public Health Bulletin No. 162. United States Public Health Service. Washington: Government Printing Office. 
[7] Burkhauser, Richard V., J.S. Butler, Jean M. Mitchell, and Theodore Pincus. 1986. "Effects of Arthritis on Wage Earnings." Journal of Gerontology. 41(2): 277-281.

[8] Coclanis, Peter and John Komlos. 1995. "Nutrition and Economic Development in PostReconstruction South Carolina: An Anthropometric History.” Social Science History. 19(1): 91-116.

[9] Condran, G.A. and R.A. Cheney. 1982. "Mortality Trends in Philadelphia: Age-specific and cause-specific death rates 1870-1930." Demography. 19(11):97-123.

[10] Costa, Dora L. 1996. "Health and Labor Force Participation of Older Men, 1900-1991." Journal of Economic History. Forthcoming, March.

[11] - 1995. "Pensions and Unemployment: Evidence from Union Army Veterans." Quarterly Journal of Economics. 110(2): 297-320.

[12] - 1994. "Health of Young Adults: Evidence, Causes, and Outcomes." Grant proposal submitted to NIH.

[13] - 1993a. "Height, Wealth, and Disease among the Native-born in the Rural, Antebellum North." Social Science History. 17(3): 355-383.

[14] - 1993b. "Height, Weight, Wartime Stress, and Older Age Mortality: Evidence from the Union Army Records." Explorations in Economic History. 30(4): 424-49.

[15] Crimmins, E.M. 1984. "Life expectancy and the older population: Demographic implications of recent and prospective trends in old age mortality." Research on Aging. 6(4): 490-514.

[16] Cuff, Timothy. 1994. "The Body Mass Index Values of Mid-Nineteenth- Century West Point Cadets: A Theoretical Application of Waaler's Curves to a Historical Population." Historical Methods 26(4): 171-82.

[17] Curtin, Philip D. 1989. Death by Migration. Cambridge: Cambridge University Press.

[18] Dasgupta, Partha. 1993. An Inquiry into Well-being and Destitution. Oxford: Clarendon Press; New York: Oxford University Press.

[19] Davin, Eric Leif. 1993. "The Era of the Common Child: Egalitarian Death in Antebellum America." Mid-America: An Historical Review. 75(2): 135-163.

[20] Davis, Lance E. et al. 1972. American Economic Growth. New York: Harper and Row.

[21] Deolaliker, Anil B. 1988. "Do Health and Nutrition Influence Labor Productivity in Agriculture? Econometric Estimates for Rural South India." The Review of Economics and Statistics. 70(2): 406-413. 
[22] Durnin, J.V.G.A. and J. Womersley. 1974. "Body fat assessed from cotal body density and its estimation from skinfold thickness: measurements on 481 men and women aged from 16 to 72 years." British Journal of Nutrition. 32(1): 77-97.

[23] Eveleth, Phyllis B. and James M. Tanner. 1990. Worldwide Variation in Human Growth. Cambridge: Cambridge University Press.

[24] Floud, Roderick, Kenneth W. Wachter, and Anabel S. Gregory. 1990. Height, Health, and History: Nutritional Status in the United Kingdom, 1750-1980. Cambridge: Cambridge University Press.

[25] Fogel, Robert W. 1986. "Nutrition and the Decline in Mortality since 1700: Some Preliminary Findings.” In S.L. Engerman and R.E. Gallman (Eds.), Long-term Factors in American Economic Growth. Chicago: University of Chicago Press.

[26] Fogel, Robert W., Dora L. Costa, and John M. Kim. 1994. "Secular Trends in the Distribution of Chronic Conditions and Disabilities at Young Adult and Late Ages, 1860-1988: Some Preliminary Findings." Unpublished Manuscript. University of Chicago.

[27] Folsom AR, Prineas RJ, Kaye SA, et al. 1989. "Body fat distribution and self-reported prevalence of hypertension, heart attack, and heart disease in older women." International Journal of Epidemiology. 18(2): 361-7.

[28] Folsom AR, Kaye SA, Sellers TA, Hong CP, Cerhan JR, Potter JD, Prineas RJ. 1993. "Body Fat Distribution and 5-Year Risk of Death in Older Women." Journal of the American Medical Association. 269(4): 483-87.

[29] Foster Andrew D. and Mark R. Rosenzweig. 1992. "Information Flows and Discrimination in Rural Areas in Developing Countries." Proceedings of the World Bank Annual Conference on Development Economics. Washington: World Bank: 173-203.

[30] Gallman, Robert E. 1966. "Gross national product in the United States, 1834-1909." In D.S. Brady (Ed.), Output, Employment, and Productivity. Studies in Income and Wealth 30 . New York: National Bureau of Economic Research.

[31] Goldin, Claudia and Robert A. Margo. 1992. "Wages, Prices, and Labor Markets before the Civil War." In C. Goldin and H. Rockoff (Eds.), Strategic Factors in Nineteenth Century American Economic History: A Volume to Honor Robert W. Fogel. Chicago: University of Chicago Press: 67-104.

[32] Goldin, Claudia and Kenneth Sokoloff. 1982. "Women, Children, and Industrialization in the Early Republic: Evidence from the Manufacturing Censuses." Journal of Economic History. 42(4): 741-74.

[33] Gruenwald P. 1963. "Chronic fetal distress and placental insufficiency." Biology of the Neonate 5: 216-65. 
[34] Haddad Lawrence J. and Howarth E. Bouis. 1991. "The Impact of Nutritional Status on Agricultural Productivity: Wage Evidence from the Philippines." Oxford Bulletin of Economics and Statistics. 53(1): 46-68.

[35] Haines, Michael R. 1994. "Estimated Life Tables for the United States, 1850-1900." NBER Working Paper Series on Historical Factors in Long Run Growth. Historical Paper No. 59.

[36] Hartz AJ, Rupley DC, and Rimm AA. 1984. "The association of girth measurements with disease in 32, 856 women." American Journal of Epidemiology. 119(1): 71-80.

[37] Hathaway, Millicent L. and Elsie D. Foard. 1960. Heights and Weights of Adults in the United States. Human Nutrition Research Division. Agricultural Research Service. United States Department of Agriculture. Home Economics Research Report No. 10. Washington: Government Printing Office.

[38] Higgs, Robert. 1979. "Cycles and trends of mortality in 18 large American cities, 18711900." Explorations in Economic History. 16(4): 381-408.

[39] Kansas Bureau of Labor and Industry. "1,204 Wage-Earners in Kansas, 1897." Thirteenth Annual Report of the Kansas Bureau of Labor and Industry. Machine readable data. Historical Labor Statistics Project. Institute of Business and Economic Research. University of California. Ber'ivicy, $\mathrm{C}_{\hat{A}}$.

[40] Karpinos, Bernard D. 1958. "Height and Weight of Selective Service Registrants Processed for Military Service During World War II.” Human Biology. 30: 292-321.

[41] Komlos, John. 1990. "Height and Social Status in Eighteenth-Century Germany." Journal of Interdisciplinary History. 20(4): 607-21.

[42] 1989. Nutrition and Economic Development in the Eighteenth-Century Habsburg Monarchy. Princeton: Princeton University Press.

[43] - 1987. "The Height and Weight of West Point Cadets: Dietary Change in Antebellum America." Journal of Economic History. 47(4): 897-927.

[44] Kunitz, Stephen J. and Stanley L. Engerman. 1992. "The Ranks of Death: Secular Trends in Income and Mortality." Health Transition Review. 2 (Suppl.): 29-46.

[45] Lee, Chulhee. 1995. "Socioeconomic Background, Disease, and Mortality among Union Army Recruits: Implications for Economic and Demographic History." Unpublished manuscript. Center for Population Economics, University of Chicago.

[46] Livi-Bacci, Massimo. 1991. Population and Nutrition: An Essay on European Demographic History. Cambridge: Cambridge University Press. 
[47] Makela, M., Heliovaara, M., Sievers, K., Impivaara, O., Knekt, P., and Aromaa, A. 199!. "Prevalence, Determinants, and Consequences of Chronic Neck Pain in Finland." American Journal of Epidemiology. 134(11): 1356-67.

[48] Margo, Robert A. and Richard H. Steckel. 1992. "The Nutrition and Health of Slaves and Antebellum Southern Whites." In R.W. Fogel and S.L. Engerman (Eds.), Without Consent or Contract: Conditions of Slave Life and the Transition to Freedom. New York: W.W. Norton: 508-21.

[49] - 1982. "The Heights of American Slaves: New Evidence on Slave Nutrition and Health." Social Science History. 6(4): 516-38.

[50] Martorell, Reynaldo and Jean-Pierre Habicht. 1986. "Growth in early childhood in developing countries." In F. Falkner and J.M. Tanner (Eds.), Human Growth: A Comprehensive Treatise, Volume 3. New York: Plenum Press.

[51] May, Jacques M. 1958. The Ecology of Human Disease. New York: MD Publications.

[52] Morris, Morris David. 1979. Measuring the Condition of the World's Poor: The Physical Quality of Life Index. New York: Pergamon Press.

[53] Negri, E., Pagano, R., Decarli, A., and La Vecchia, C. 1988. "Body Weight and the Prevalence of Chronic Diseases." Journal of Epidemiology and Community Health 42(1): 24-9.

[54] Nicholas, Stephen and Richard H. Steckel. 1992. "Tall but Poor: Nutrition, Health, and Living Standards in Pre-Famine Ireland." NBER Working Paper Series on Historical Factors in Long Run Growth. No. 39. Cambridge, MA.

[55] Noord PAH Van, Seidell JC, Den Tronkelaar I, Baabders-Van Halewijn EA, and Ouwehand IJ. 1990. "The Relationship between Fat Distribution and Some Chronic Diseases in 11825 Women Participating in the DOM-Project." International Journal of Epidemiology. 19(3): 564-70.

[56] Nygärd, C-H., T. Luopajärvi, and J. Illmarinen. 1988. "Musculoskeletal capacity of middleaged women and men in physical, mental and mixed occupations." European Journal of Applied Physiology. 57(2): 181-188.

[57] Ohlson LO, Larsson B, Svardsudd K, et al. 1985. "The influenceof body fat distribution on the incidence of diabetes mellitus. 13.5 years of follow-up of the participants in the study of men born in 1913." Diabetes. 34(10): 1055-8.

[58] Pope, Clayne L. 1992. "Adult Mortality in America before 1900: A View from Family Histories." In C. Goldin and H. Rockoff (Eds.), Strategic Factors in Nineteenth Century American Economic History: A Volume to Honor Robert W. Fogel. Chicago: University of Chicago Press: 267-96. 
[59] Preston, Samuel H. 1993. "Demographic Change in the United States, 1970-2050." In K.G. Manton, B.H. Singer, and R.M. Suzman (Eds.), Forecasting the Health of Elderly Populations. New York: Springer-Verlag: 51-78.

[60] Preston, Samuel H. and Michael R. Haines. 1991. Fatal Years: Child Mortality in Late Nineteenth Century America. Princeton: Princeton University Press.

[61] Preston, Samuel H., Nathan Keyfitz, and Robert Schoen. 1972. Causes of death: life tables for national population. New York: Seminar Press.

[62] Roman Diaz, M. 1992. "Prevalencia de Obesidad y Condiciones Asociades en un Centro de Medicina de Familia.” Boletin-Asociacion Medica de Puerto Rico. 84(11): 302-4.

[63] Rosen, Sherwin. 1988. "The Value of changes in Life Expectancy." Journal of Risk and Uncertainty. 1: 285-304.

[64] Sandberg, Lars G. and Richard H. Steckel. 1988. "Overpopulation and Malnutrition Rediscovered: Hard Times in Nineteenth Century Sweden." Explorations in Economic History. 25(1): 1-19.

[65] Shay, Ted. 1986. "The Stature of Military Conscripts: New Evidence on the Standard of Living in Japan." Paper given at the 1986 Social Science History Association meetings, St. Louis, Missouri.

[66] Shetty, P.S. 1984. "Adaptive Change in Basal Metabolic Rate and Lean Body Mass in Chronic Undernutrition." Human Nutrition-Clinical Nutrition. 38(6): 443-51.

[67] Smillie, Wilson G. 1955. Public Health: Its Promise for the Future. New York: Macmillan.

[68] Soares, M.J. and P.S. Shetty. 1991. "Basal Metabolic Rate, Body Composition and WholeBody Protein Turnover in Indian Men with Differing Nutritional Status." Clinical Science. 81(3): 419-25.

[69] Sokoloff, Kenneth L. and Georgia C. Villaflor. 1982. "The Early Achievement of Modern Stature in America." Social Science History 6(4): 453-481.

[70] Soler JT, Folsom AR, Kushi LH. et al. 1988. "Association of body fat distribution with plasma lipids, lipoproteins, apolipoproteins AI and B in postmenopausal women." Journal of Clinical Epidemiology. 41(11): 1075-81.

[71] Steckel, Richard H. 1995. "Stature and the Standard of Living." Journal of Economic Literature. 33(4): 1903-40.

[72] — 1994. "Census Manuscript Schedules Matched with Property Tax Lists: A Source of Information on Long-Term Trends in Wealth Inequality." Historical Methods 27(2): 71-85. 
[73] - 1992. "Stature and Living Standards in the United States." In R.E. Gallman and J.J. Wallis (Eds.), American Economic Growth and Standards of Living Before the Civil War.

[74] - 1988. "The Health and Mortality of Women and Children, 1850-1860." Journal of Economic History. 48: 333-345.

[75] _ 1979a. "Slave Height Profiles from Coastwise Manifests." Explorations in Economic History. 16(4): 363-380.

[76] — 1979b. "Slave Mortality: Analysis of Evidence from Plantation Records." Social Science History 3(3,4): 86-114.

[77] Steckel, Richard H. and Donald R. Haurin 1982. "Height, Nutrition, and Mortality in Ohio, 1870-1900.” Mimeo. Columbus, Ohio.

[78] Terry RB, Page WF, and Haskell WL. 1992. "Waist/hip ratio, body mass index and premature cardiovascular disease mortality in US Army veterans during a twenty-three year follow-up study." International Journal of Obesity. 16(6): 417-23.

[79] Thaler, Richard and Sherwin Rosen. 1976. "The Value of Saving a Life: Evidence from the Labor Market," In N.E. Terleckyj (Ed), Household Production and Consumption. New York: National Bureau of Economic Research: 265-298.

[80] Tverdal, A. 1988. "Height, weight, and incidence of tuberculosis." Bulletin of the International Union Against Tuberculosis and Lung Disease. 63(2): 16-18.

[81] United Nations. 1990. Human Development Report 1990. New York and Oxford:Oxford University Press.

[82] U.S. Bureau of the Census. 1975. Historical Statistics of the United States, Colonial Times to 1970. Washington, D.C.: U.S. Government Printing Office.

[83] Usher, Dan. 1973. "An imputation to the measurement of economic growth for changes in life expectancy." In M. Moss (Ed.), The Measurement of Economic and Social Performance. New York: Columbia University Press: 193-226.

[84] Usher, Dan. 1980. The Measurement of Economic Growth. New York: Columbia University Press.

[85] Vague J. 1956. "The degree of masculine differentiation of obesities: a factor determining predisposition to diabetes, atherosclerosis, gout, and uric calculous disease." American Journal of Clinical Nutrition. 4: 20-34.

[86] Viscusi, W. Kip. 1978. "Wealth Effects and Earnings Premiums for Job Hazards.” Review of Economics and Statistics. 60(3): 408-416. 
[87] Waaler, H.T. 1984. "Height, Weight, and Mortality. The Norwegian Experience." Acta Medica Scandinavica [Suppl.]. 679(Suppl.): 1-56.

[88] Ward, Peter W. 1993. Birth Weight and Economic Growth: Women's Living Standards in the Industrializing West. Chicago: University of Chicago Press.

[89] Weiss, Thomas. 1992. "U.S. Labor Force Estimates and Economic Growth, 1800-1860." In R.E. Gallman and J.J. Wallis (Eds.), American Economic Growth and Standards of Living Before the Civil War. Chicago: University of Chicago Press: 19-78.

[90] Williamson, J.G. 1984. "British Mortality and the Value of Life, 1781-1931." Population Studies. 38(1): 157-172.

[91] Yelin EH and Katz P. 1991. "Labor Force Participation Among Persons with Musculoskeletal Conditions, 1970-1987." Arthritis and Rheumatism. 34(11): 1361-1370. 